\title{
Methodological notes
}

\section{Trade in goods (Chapter 2)}

\section{Introduction}

The IMF Balance of Payments Manual, 5th edition (BPM5) defines trade in goods as covering general merchandise, goods for processing, repairs on goods, goods procured in ports by carriers, and non-monetary gold.

General merchandise (with some exceptions) refers to moveable goods for which real or imputed changes of ownership occur between UK residents and the rest of the world.

Goods for processing: this covers goods that are exported or imported for processing and that comprise two transactions: the export of a good and the re-importation of the good on the basis of a contract and for a fee or the import of a good and the re-exportation of the good on the basis of a contract and for a fee. The inclusion of these transactions on a gross basis is an exception to the change of ownership principle. The value of the good before and after processing is recorded. This is included in total trade in goods but cannot be separately identified.

Repairs on goods: this covers repairs that involve work performed by residents on movable goods owned by non-residents (or vice versa). Examples of such goods are ships, aircraft and other transport equipment. The value recorded is the value of the repairs (fee paid or received) rather than the value of the goods before and after repair.

Goods procured in ports: this covers goods such as fuels, provisions, stores and supplies procured by UK resident carriers abroad or by non-resident carriers in the UK.

Non-monetary gold: this is defined as all gold not held as reserve assets (monetary gold) by the authorities. Non-monetary gold can be subdivided into gold held as a store of value and other (industrial) gold - for further information see the Glossary.

\section{Coverage and other adjustments}

The balance of payments statistics of trade in goods compiled by the Office for National Statistics (ONS) are derived principally from data published by HM Revenue \& Customs (HMRC) on the physical goods exported from and imported to the UK. However, this information is on a different basis to that required for balance of payments statistics. Accordingly in order to conform to the IMF definitions ONS has to make various adjustments to include certain transactions which are not reported to HMRC and to exclude certain transactions which are reported to them but where there is no change of ownership. In addition, the value required for balance of payments purposes is the value of goods at the point of export (that is, the Customs border of the exporting country) rather than the value of goods as they arrive in the UK. Therefore, the freight and insurance costs of transporting the goods to the UK needs to be deducted from the values recorded by HMRC. Table 2.4 summarises this transition onto a balance of payments for each of the last 11 years.

\section{Overseas trade statistics compiled by HM Revenue \& Customs (HMRC)}

Statistics of the UK's overseas trade in goods have been collected for over 300 years by HMRC, formerly HM Customs and Excise (HMCE). Since 1993 these data comprise statistics of UK imports from and exports to countries outside the EU and statistics on trade with other EU member states collected via the Intrastat survey. Data are compiled from declarations made to HMRC by importers, exporters or their agents AND statistics of UK arrivals (imports) from and dispatches (exports) to other member states of the EU compiled from the Intrastat returns submitted by traders or their agents to HMRC.

Prior to 1993 statistics of UK imports from and exports to all countries in the world were compiled from declarations made to HMRC by importers, exporters or their agents.

\section{Information on trade with EU countries}

The Intrastat system has applied since 1993, with minor variations, in all EU member states. In the UK all VAT registered businesses are required to complete two additional boxes on their VAT returns, which are normally submitted quarterly. These show the total value of exports of goods to customers in other member states (dispatches) and the total value of imports of goods from suppliers in other member states (arrivals).

Traders whose annual value of arrivals or dispatches exceed given thresholds are required to provide an Intrastat declaration each month, showing full details of their arrivals and dispatches during the month. These thresholds are reviewed annually. For the calendar year 2007, the thresholds were $f 260,000$, both for arrivals and for dispatches. These detailed Intrastat declarations cover approximately 97 per cent of the value of trade.

\section{Link with VAT}

The information on the VAT returns serves three purposes:

- to establish a register of traders and to determine which exceed the thresholds

- to provide a cross-check with the Intrastat declarations

- to provide an estimate of the total value of trade carried out by traders below the Intrastat thresholds.
Traders not registered for VAT and private individuals who move goods within the EU have no obligations under the Intrastat system and their trade is therefore not included in the statistics. Examples of commodities where this trade can be significant are works of art and racehorses.

\section{Below threshold trade}

The total values of arrivals and dispatches by traders below the Intrastat thresholds are available from their VAT returns, although the coverage is slightly different. The figures are included in the month in which the VAT return is received by HMRC, although the VAT return itself may relate to a period of more than one month. Detailed information on below threshold trade is not available from the VAT data. However, it has been established that the pattern of that trade before the Intrastat system was introduced on 1 January 1993 was similar to that of traders just above the thresholds. Thus estimates enabling detailed allocations of below threshold trade can be made on this basis by HMRC.

\section{Late response}

Traders who have a legal responsibility to provide Intrastat declarations are required to do so by the end of the calendar month following the month to which the declaration relates. However, where traders have failed to provide returns to Intrastat by the due date, estimates of the total value of such trade are included. These are based on the trade reported by these traders in a previous period, and the growth rate since that period experienced by comparable traders who have provided returns for the current month.

Late declarations of trade with EU countries are subsequently incorporated into the month's figures to which they relate with a corresponding reassessment of the initial estimates for late response.

The methodology used to collect EU (Intrastat) data on Natural Gas and Electricity was amended by the Commission of the European Communities (EC regulation no 1982/2004). As a result, from January 2005, HM Revenue \& Customs (HMRC) has changed to collecting information relating to the trade in Natural Gas and Electricity directly from the pipeline and grid operators. This has removed the need for individual companies to submit Intrastat (EU) import and export declarations for these goods. The new methodology records the physical flow of Natural Gas and Electricity between the UK and the last country at the point the goods cross the border into the UK. Value data are estimated using the relevant market prices for gas and electricity.

\section{Information on trade with non-EU countries}

In general the figures for trade with non-EU countries show the trade as declared by 
importers and exporters or their agents and for which documentation has been received and processed by HMRC during the month.

Importers are usually required to present a Customs declaration before they can obtain Customs clearance and remove the goods. The great majority of imports are cleared immediately by a computerised system. Furthermore the import statistics include documents received by HMRC up to the third working day after the end of the month. Therefore the import figures correspond fairly closely to goods actually imported during the calendar month. Generally speaking about 90 per cent by value and 85 per cent by number of all entries relate to the calendar month with the bulk of the remainder relating to the immediately preceding month.

Under the procedures for the control of exports, the principle is the same - namely that goods cannot be cleared for export until a Customs declaration has been made. Traders can, if they wish, submit a simplified declaration so that the goods can be exported, which has to be followed within 14 days after date of shipment with a complete export declaration. Moreover the processing of these complete export documents begins three working days before the end of the calendar month (two working days for December). Thus the export statistics compiled for a month (which are based on the date of receipt of the complete export documents) do not correspond with goods actually shipped in the calendar month. Generally both in terms of the value and the number of documents, 70 per cent relates to the calendar month with the bulk of the remaining 30 per cent relating to the immediately preceding month.

HMRC's New Export System (NES), which replaced manual (paper) Customs declarations with electronic submissions, requires electronic messages from the trade once the goods have been exported in order to provide the departure date. The new system has led to greater efficiency; improving processing and thereby speeding up the flow of information. This means that, in terms of the value of trade, the proportion allocated to the correct month has increased from September 2003 onwards.

\section{Basis of valuation}

For statistical purposes the UK adopts the valuation bases recommended in the International Merchandise Trade Statistics Concepts \& Definitions published by the United Nations.

The valuation of exports (dispatches) is on a free on board (f.o.b.) basis, that is, the cost of goods to the purchaser abroad, including:

- packaging

- inland and coastal transport in the UK

- dock dues

- loading charges

- all other costs such as profits, charges and expenses (for example, insurance) accruing up to the point where the goods are deposited on board the exporting vessel or aircraft or at the land boundary of Northern Ireland

The valuation of imports (arrivals) is on a cost, insurance and freight (c.i.f.) basis including
- the cost of the goods

- charges for freight and insurance

- all other related expenses in moving the goods to the point of entry into the UK (but excluding any duty or tax chargeable in the UK)

When goods are re-imported after process or repair abroad the value includes the cost of the process or repair as well as the value of the goods when exported

\section{Arrivals from and dispatches to EU countries}

As part of the simplification procedure to reduce the burden on business, in the UK most traders are permitted to provide a valuation for trade in goods with EU countries based on the invoice value. Large traders, currently those who have more than $\mathrm{f} 14$ million of trade in the year, are required to supply information on their delivery terms. Regular sample surveys to all traders are conducted by HMRC to establish conversion factors to adjust the invoice values to produce the valuation basis required for statistical purposes. Separate factors are imputed for a range of different delivery terms and for trade with each member state.

The value recorded for arrivals and dispatches includes any duties or levies that have been applied to goods originating in non-EU countries but which have since cleared EU Customs procedures in one EU country prior to moving onto other EU countries.

\section{Imports from non-EU countries}

The statistical value of imports of goods subject to duty is the same as the value for Customs purposes. This value is arrived at by the use of specific methods of valuation in the following order of preference:

- the transaction value of the imported goods (that is, the price paid or payable on the goods)

- the transaction value of identical goods

- the transaction value of similar goods

- the 'deductive method' - value derived from the selling price in the country of importation

- computed value based on the built-up cost of the imported goods

Imported goods are valued at the point where the goods are introduced into the Customs territory of the EU. This means that costs for delivery of the imported goods to that point have to be included in the Customs value.

For all other goods (that is, goods free or exempted from duty and goods subject to a specific duty) the statistical value is determined in relation to the point at which the goods enter the UK.

An amount expressed in foreign currency is converted to sterling by the importer using a system of 'period rates of exchange' published by HMRC. These rates are normally operative for a four weekly period unless there is a significant movement in the exchange rate.

\section{Treatment of taxes}

As described above, the value of all goods moving into and out of the UK is based on the transaction value recorded for Customs purposes or, in the case of trade in goods with EU countries, the invoice or contract value. In line with this principle, the values recorded exclude VAT. For trade in goods with non-EU countries, all other taxes such as duties and levies applied to goods after arrival in the UK are excluded. For trade in goods with EU countries, the value recorded for imports and exports includes any duties or levies that have been applied to goods originating in non-EU countries but which have since cleared Customs procedures prior to moving onto other EU countries. However excise duties are excluded from the value recorded for trade.

\section{Balance of payments statistics for trade compiled by ONS}

Table 2.4 summarises the transition from trade in goods statistics on an Overseas Trade Statistics basis (compiled and published by HMRC) to those on a Balance of Payments basis (compiled by ONS)

\section{Valuation adjustments}

Freight: the cost of freight services for the sea legs of dry cargo imports is estimated by applying freight rates (derived from the rates for a large sample of individual commodities imported from various countries) to tonnages of goods arriving by sea. For the land legs, estimates of freight rates per tonnekilometre for different commodities and estimated distances are used. Estimates of rail freight through the Channel Tunnel are estimated from data provided by Le Shuttle and freight operators. The cost of freight on imports arriving by air is derived from information on the earnings of UK airlines on UK imports and the respective tonnages landed by UK and foreign airlines at UK airports. Pending investigations of an alternative methodology the cost of freight and insurance on oil and gas imports is projected from data formerly supplied by the Department of Trade and Industry.

Sources: tonnages from HMRC; information on freight rates from Chamber of Shipping, Civil Aviation Authority and road hauliers; information from Eurotunnel.

Insurance: the cost of insurance premiums on non-oil imports is estimated as a fixed percentage of the value of imports.

Source: ONS estimate.

\section{Coverage adjustments}

Second-hand ships: to include purchases and sales of second-hand ships which are excluded from the Overseas Trade Statistics as the transactions are not included in the IMTS definition.

Source: inquiries to UK ship owners conducted by the Department for Transport until late 2005 Estimates are now provided by HMRC.

New ships delivered abroad: to include deliveries of new ships built abroad for UK owners while the vessel is still in a foreign port as the transactions are not included in the IMTS definition.

Source: inquiries to UK ship owners conducted by the Department for Transport until late 2005 Estimates are now provided by HMRC.

North Sea installations: to include goods (including drilling rigs) directly exported from 
and imported to the UK production sites in the North Sea. This adjustment is also used when there is a redistribution of the resources of fields which lie in both UK and non-UK territorial waters (for example, the Frigg, Murchison and Statfjord). In these circumstances the contribution to (or reimbursement of) a proportion of the development costs has been treated as a purchase (or sale) of fixed assets at the date of the re-determination and appears as an adjustment to imports (exports) of goods

Source: ONS inquiries to the petroleum and natural gas industry.

NAAFI: to exclude goods exported by the Navy, Army and Air Force Institute for the use of UK forces abroad since these are regarded as sales to UK residents.

\section{Source: quarterly returns from NAAFI.}

Goods not changing ownership: the Overseas Trade Statistics exclude temporary trade (that is, goods that are to be returned to the original country within two years and there is no change of ownership). However, goods may well have originally been recorded as 'genuine' trade but which are subsequently returned to the original country. Examples of these 'returned goods' are goods traded on a 'sale or return' basis; goods damaged in transit and returned for replacement or repair; and contractor's plant. The same amount is deducted from both imports and exports for the month in which the return movement is declared to Customs.

Source: HMRC (non EU trade in goods identified by reference to Customs Procedure codes (CPCS) and by 'Nature of Transaction Code' on Intrastat submissions).

Gold: trade in gold (that is, gold bullion, gold coin, unwrought or semi-manufactured gold and scrap) is reported to HMRC but it is excluded from the statistics of total exports and imports published in the Overseas Trade Statistics. However, trade in ores and concentrates and finished manufactures of gold (for example, jewellery) are included in total exports and imports.

For Balance of Payments purposes, all trade in non-monetary gold should be included under trade in goods. Non-monetary gold is defined as all gold not held as reserve assets (monetary gold) by the authorities. Nonmonetary gold can be subdivided into gold held as a store of value and other (industrial) gold. The UK currently makes adjustments to include industrial gold. In exports, the adjustment reflects the value added in refining gold and producing proof coins. In imports, the adjustment reflects the value of gold used in finished manufactures (such as jewellery and dentistry).

Within the transactions of the London Bullion Market, the UK cannot currently distinguish between monetary gold and non-monetary gold held as a store of value. Accordingly, the UK has obtained an exemption from adopting IMF recommendations, as specified in BPM5 and for the time being these transactions are included in the Financial Account.

The treatment of non-monetary gold is being reviewed as part of the worldwide process to revise the IMF Balance of Payments manual. UK BoP will continue current practice until the treatments defined in the revised manual are implemented.

\section{Source: ONS estimate.}

Letter post: to include exports by letter post which are not included in the Overseas Trade Statistics.

Sources: books - ONS estimate based on historic information from publishers and booksellers; other items - ONS estimate based on historic sample inquiry made by the former Post Office.

Additions and alterations to ships: to include work carried out abroad on UK owned ships and work carried out in UK yards on foreign owned ships.

Sources: Inquiries to UK ship owners conducted by the Department for Transport, (imports) until late 2005, then HMRC, and ONS estimates (exports).

Repairs to aircraft: to include the value of repairs carried out in the UK on foreign owned aircraft.

\section{Source: ONS estimate.}

Goods procured in ports: to include fuels, provisions, stores and supplies purchased for commercial use in ships, aircraft and vehicles. (Estimates of goods dispatched are recorded by HMRC.)

Sources: Chamber of Shipping and Civil Aviation Authority for goods procured in foreign ports by UK transport companies (imports); UK oil companies, Civil Aviation Authority, BAA, municipal airports and port authorities for goods procured in UK ports by overseas transport companies (exports).

Smuggling of alcohol and tobacco: Customs provide volume figures for smuggled goods entering the UK based on published estimates of revenue loss and revenue evasion through smuggling. This information is supplemented by information on the average prices for alcohol and tobacco goods in France and Belgium from the published sources of the statistical and banking institutions in those countries in order to estimate the value of smuggled alcohol and tobacco entering the UK.

Sources: HMRC, INSEE and National Bank of Belgium.

Territorial coverage adjustment: for the purposes of the Overseas Trade Statistics, 'UK' is defined as Great Britain, Northern Ireland, the Isle of Man, the Channel Islands and the Continental Shelf (UK part). Therefore the Overseas Trade Statistics exclude trade between these different parts of the UK but include their trade with other countries.

For balance of payments purposes the Channe Islands and the Isle of Man are not considered part of the UK economic territory. Adjustments are made to exports to include UK exports to those islands and to exclude their exports to other countries; and to imports to include UK imports from those islands and to exclude their imports from other countries.

Source: ONS estimate.

\section{Other adjustments}

Diamonds: much of the World's trade in rough (uncut) diamonds is controlled from London by the Diamond Trading Company, part of De Beers. Prior to 2001, in order not to distort the trade statistics, all imports into and exports from the UK of uncut diamonds which remain in the ownership of foreign principles are excluded from the Overseas Trade Statistics by HMRC. In addition the value of diamonds imported into the UK can be reassessed after the diamonds have been cleared by Customs. Prior to 2001, this adjustment reflects these changes in valuation. From 2001 the procedure for recording movements of diamonds was changed so that all trade was included in the Overseas Trade Statistics by HMRC. From 2001, this adjustment removes movements of diamonds where no change of ownership has taken place.

\section{Source: Diamond Trading Company.}

Adjustments to imports for the impact of VAT Missing Trader Intra-Community (MTIC) fraud: VAT intra-Community missing trader fraud is a systematic, criminal attack on the VAT system, which has been detected in many EU member states. In essence, fraudsters obtain VAT registration to acquire goods VAT free from other member states. They then sell on the goods at VAT inclusive prices and disappear without paying over the VAT from their customers to the tax authorities. The fraud is often carried out very quickly, with the fraudsters disappearing by the time the tax authorities follow up the registration with their regular assurance activities.

Acquisition fraud is where the goods are imported from the EU into the UK by a trader who then goes missing without completing a VAT return or Intrastat declaration. The 'missing trader' therefore has a VAT free supply of goods, as they make no payment of the VAT monies due on the goods. He sells the goods to a buyer in the UK and the goods are available on the home market for consumption.

Carousel fraud is similar to acquisition fraud in the early stages, but the goods are not sold for consumption on the home market. Rather, they are sold through a series of companies in the UK and then re-exported to another country. Goods may be imported and exported several times, hence the goods moving in a circular pattern or 'carousel'.

The VAT system (and therefore the Intrastat collection of trade statistics) picks up the exports of any 'carouselled' goods, but does not always pick up the associated import at the time the carouselled goods entered the UK. As a consequence, UK import statistics had been under reported

Originally, most carousel chains only involved EU member states. From the beginning of 2004 there was an increase in carousel chains that involve non-EU countries, for example, Dubai and Switzerland. However, the MTIC trade adjustments are added to the EU import estimates derived from Intrastat returns as it is this part of the trading chain that is not recorded. Changes to the pattern of trading associated with MTIC fraud can therefore make it difficult to analyse trade by commodity group and by country. In particular, adjustments affect 
trade in capital goods and intermediate goods these categories include mobile phones and computer components (now covered by the UK's reverse charge derogation)

HMRC estimate for the impact of MTIC on the trade statistics. The method used relies heavily on information uncovered during HMRC's operational activity and as such it cannot be detailed for risk of prejudicing current activity, including criminal investigations and prosecutions and more generally undermining HMRC's ability to tackle the fraud effectively. The method specifically excludes adjustments for the acquisition variant of the fraud which cannot be quantified at present. HMRC regularly reviews the methodology for producing the estimates of the impact on the trade statistics to take account of mutations in the fraud. Estimates may change as the analysis of the fraud continues. The UK is the first member state to make adjustments in their trade statistics for this type of fraud

Source: HMRC estimate

Adjustment for under-recording and for currency and other valuation errors: these adjustments compensate for the following types of error:

- failure on the part of traders or their agents to submit details of shipments

- incorrect valuations recorded

- declarations wrongly given in foreign currency instead of sterling

Regular reviews show the adjustments for non EU trade remaining broadly constant over time. Those for EU trade have reduced since the early days of the Intrastat system. The adjustments, expressed as percentages of total trade excluding oil and erratics, are shown in table 1.

Adjustments to estimates for late response: a review of the introduction of the Intrastat system carried out in 1994 identified a number of difficulties in the initial monthly estimates of trade with EU countries provided by HMRC. The following describes the adjustments made by ONS to cope with these difficulties.

The HMRC method of estimation for late response relies on linking the values of trade reported by traders in the current period with previous periods. Problems can arise when traders change their VAT registration (perhaps as a result of an internal reorganisation, mergers or sales).

Similarly problems can arise when a trader starts submitting returns for the first time. If the trader then becomes a late responder there may be no history of previous trade upon which to base an estimate. The current HMRC adjustments make an allowance for this, but recent changes in the overall trader profile, with an increasing proportion of smaller traders, means the current methodology needs to be revised. In the meantime, ONS and HMRC have agreed that ONS makes an initial adjustment of $+\mathrm{f} 30$ million to both exports and imports (reducing to zero over the following two months).

Furthermore, some traders may submit first declarations for a month that do not include all their trade in that month. Later declarations are then received for the rest of their trade. The pattern of receipt at HMRC of these partial returns is analysed to enable ONS to make initial adjustments to both exports and imports to anticipate these later declarations. These initial adjustments are progressively reduced in subsequent months as late declarations are processed.

Currently the profile of these adjustments is as shown in table 2

When Intrastat was introduced it was envisaged that all declarations in respect of any particular month would be made within 6 months of the end of that month. As a consequence HMRC computer programs were designed to recalculate its initial estimates for late response for six months after those estimates first appear in the Overseas Trade Statistics. However the reality is that some declarations are still being received and processed after that six month period. These are being included as additions to the value of reported trade with no corresponding reduction in the value of estimated trade. Accordingly, in order to eliminate this element of double counting ONS makes a negative adjustment to the value of estimated trade equal to the value of these late amendments. Note that where the value of late amendments exceeds the value of estimated trade the level of estimated trade is set to zero.

Source: ONS estimate.

\section{Price and volume indices}

Any difference between time periods in the total value of trade reflects changes in prices as well as changes in the levels of the underlying economic activity (for example, the physical amounts of goods exported or imported). Separation of these changes greatly enhances the interpretation of the data and, for this reason, ONS compiles separate data measuring changes in price and changes in volume. These data are presented in index number form.

\section{Classifications and definitions}

The Overseas Trade Statistics (OTS), on which the trade data are based, have been compiled under the United Nations Standard International Trade Classification Revision 4 (SITC R4) from January 2007 but the data have been converted back to SITC R3 for these releases and the Monthly Review of External Trade Statistics (MRETS) publication in order to help users to compare data over time. There are some discontinuities at detailed levels, particularly between capital and intermediate goods where some products are allocated from January 2007 to intermediate goods rather than capital goods as done previously. It is also possible that volume and price changes between 2006 and 2007 may be less reliable than usual.

\section{References}

Aggregate estimates of trade in goods, seasonally adjusted and on a balance of payments basis, are published monthly by National Statistics in a First Release. More detailed figures are available from the Time Series Data Service and are also contained in the Monthly Review of External Trade Statistics (Business Monitor MM24) which is available, free of charge, in electronic format as a PDF on the National Statistics website.

The latest Trade in goods First Release can be found at: www.statistics.gov.uk/StatBase/ Product.asp? vlnk=1119

The Monthly Review of External Trade Statistics, previously published as MM24, can be found at: www.statistics.gov.uk/StatBase/Product.asp?vln $\mathrm{k}=613 \&$ Pos $=\&$ ColRank $=2 \&$ Rank $=256$

An article entitled 'UK visible trade statistics the Intrastat system' was published in Economic Trends, August 1994.

An article describing MTIC fraud and its effect on BoP and the UK National Accounts was published in Economic Trends No. 597, August 2003. A copy can be found at: www.statistics.gov.uk/cci/ article. asp?id=402. A follow-up report was published on 17 February 2005 which summarised the work carried out since July 2003 to review the estimates of the impact on the trade figures; a copy can be found at www.statistics.gov.uk/cci/article.asp? id =1066

A fuller version of these methodological notes appears in Statistics on Trade in Goods (Government Statistical Service Methodological Series 36). It also describes the methodology employed to derive volume and price indices and is available on the National Statistics website at: www.statistics.gov.uk/StatBase/Product. asp?vlnk=14943.

\section{Trade in services (Chapter 3)}

\section{Introduction}

Trade in services covers the provision of services by UK residents to non-residents and vice versa. Trade in services are disaggregated into eleven broad categories of services, as follows:

- Transportation (Sea, Air and Other) Passenger, freight and other

\section{Table 1}

\begin{tabular}{lllll}
\hline & \multicolumn{2}{c}{ Exports to: } & \multicolumn{2}{c}{ Imports from: } \\
\cline { 2 - 5 } & EU & non-EU & EU & non-EU \\
\hline Under recording & $+1 / 4 \%$ & $+1 \frac{1}{2} \%$ & $+1 / 4 \%$ & 0 \\
Currency errors & 0 & $-1 / 2 \%$ & 0 & 0 \\
Other valuation errors & 0 & $-1 / 4 \%$ & 0 & 0
\end{tabular}

* $\left(+1 \%\right.$ for $1997 \&+1 \frac{1}{2} \%$ \% 1993-1996)

Source: quality surveys conducted by HMRC 
- Travel (Business and Personal)

- Communications services

- Construction services

- Insurance services

- Financial services

- Computer and information services

- Royalties and licence fees

- Other business services (Merchanting and other trade-related services; operational leasing services; miscellaneous business, professional and technical services)

- Personal, cultural and recreational services (Audio-visual and related services; other cultural and recreational services)

\section{- Government services}

Separate tables appear at chapter 3 of this publication for each of the above categories except construction services, which are shown in the trade in services summary table 3.1.

Trade in services data has been compiled and presented on a product rather than an industry basis since the 1998 Pink Book, when the BPM5 changes were implemented. The introduction of the International Trade in Services (ITIS) survey in 1996 facilitated this change. A full product-based dataset is available from this date. Account totals, and some additional product estimates have been constructed back to 1991 or 1992 based on the relationship between the new ITIS data and the previous industry-based data. For the transport, travel, royalties and government services accounts, there were only small changes from the industry-based data, and it was possible to construct longer time series.

\section{Construction services (shown within Table 3.1)}

Construction services cover work done on construction projects and installations by employees of an enterprise in locations outside the resident economic territory of the enterprise. The source of information is the International Trade in Services (ITIS) survey. For construction services, where a permanent base is established which is intended to operate for over a year, the enterprise becomes part of the host economy and its transactions are excluded from the trade in services account. Transactions where a permanent base is established are recorded under direct investment, within investment income.

\section{Transportation services (Table 3.2)}

The transportation account covers sea, air and other (that is, rail, land, and pipeline) transport. It includes the movement of passengers and freight, and other related transport services, including chartering of ships or aircraft with crew, cargo handling, storage and warehousing, towing, pilotage and navigation, maintenance and cleaning, and commission and agents' fees associated with passenger/freight transportation.

\section{Freight and the valuation of UK trade in goods}

The trade in goods estimates included in the balance of payments value imports as they arrive in the UK f.o.b. (free on board) at the frontiers of the exporting country. This is net of the cost of freight to the UK border and any loss and damage incurred in transit to the UK. For UK importers who purchase goods f.o.b. and arrange transport themselves, their payment for the goods at the exporting countries' frontiers comprises:

(i) the value included in the trade in goods estimates (which is net of subsequent loss and damage):

(ii) the value of loss and damage incurred in transit.

In addition, such importers bear the costs of:

(iii) freight services outside the exporting countries;

(iv) insurance services (the excess of insurance premiums paid for the journeys over claims made).

Where importers purchase goods c.i.f. (cost, insurance and freight) on arrival in the UK, items (ii) to (iv) are paid by the foreign exporters in the first instance. The c.i.f. prices are set accordingly, however, and the UK importers are regarded as bearing the costs of items (i) to (iv).

Therefore, irrespective of the payment basis, items (ii) to (iv) represent costs to UK importers additional to the trade in goods entries (item i). Item (ii), the value of loss and damage, is part of the price paid to the foreign exporter and so always represents a debit entry in the balance of payments accounts. Items (iii) and (iv), freight and insurance services, also represent debit entries when provided by non-residents; where such services are provided by UK residents there is no balance of payments entry. The debit entries above relating to freight are included in imports of transportation services.
Table 2

\begin{tabular}{lrr}
\hline & Exports & Imports \\
\hline First published estimates & +600 & +650 \\
Second estimates & +250 & +250 \\
Third estimates & +120 & +150 \\
Fourth estimates & +50 & +70 \\
Fifth estimates & 0 & +20 \\
All subsequent estimates & & 0 \\
\hline
\end{tabular}

Source: HMRC
The estimates of trade in goods cover exports valued f.o.b. The valuation of exports at the UK frontier must, by definition, include any subsequent loss or damage en route to the importer. Therefore, unlike imports, there is no need to make an explicit adjustment for loss and damage to exports. However, foreign importers must additionally bear the costs of freight and insurance services for the journeys outside the UK and where such services are provided by UK residents this gives rise to credit entries in the services accounts.

The f.o.b. value for UK imports includes the cost of transport within the exporting country. Where this service is provided by a UK operator then the trade valuation of imports overstates the balance of payments effect and an offsetting credit entry is therefore included under 'Road transport'. Similarly, an offsetting debit entry is included for foreign operators' carriage of UK exports within the UK.

\section{Sea transport}

Exports by UK operators consist of freight services on UK exports (but not imports - see 'Freight and the valuation of UK trade in goods', above) and on cross-trades, the carriage of non-resident passengers and the provision to them of services, and the chartering of ships to non-residents. Exports also include port charges and other services purchased in the UK by non-resident operators. Conversely, imports comprise services purchased abroad by UK operators, their chartering of ships from non-residents, and the carriage by non-resident operators of UK imports (but not exports) and goods on UK coastal routes and UK passengers.

Statistics relating to UK operators are provided by the Chamber of Shipping (CoS), which conducts inquiries into its members' participation in foreign trade. Until 1995, inquiries covering all CoS members were made every four years, with sample surveys for intervening years. Since 1995, the CoS has surveyed all its members annually. The data from the Chamber of Shipping are uplifted to account for UK sea transport companies who are not members using estimates for the gross tonnage of the UK fleet for different types of ship.

\section{Exports}

Passenger revenue: the value of services provided to non-resident passengers comprises fares and passengers' expenditure on board. Since UK operators are not able to distinguish between fares received from UK residents and non-residents, fares collected abroad are assumed to represent fares received from nonresidents (passenger revenue collected abroad from UK residents is thought to be small and is likely to be counter-balanced by that collected in the UK from foreign residents). An estimate of passengers' expenditure on board is added. It is assumed that the non-residents' proportion of this is the same as for fares.

Freight: earnings consist of freight services on UK exports and are based on data supplied to the Chamber of Shipping. Time charter receipts include receipts for charters with crew. Time charters without crew are included within the operational leasing component of Other Business Services (table 3.9). 
Disbursements: estimates of disbursements in the UK by foreign operators are formed from a variety of sources. UK income from port charges, towage, handling costs and other port-related services was collected in 1996 from a survey of port authorities and has been projected forward from this. Crews' expenditure is estimated from information on numbers of visiting seamen, supplied by the Home Office. Regular returns are received on light dues from Trinity House. Estimates of expenditure on ships stores and on bunkers are included within the trade in goods data. Time charter payments made to UK residents are included under 'Ships owned or chartered-in by UK residents'.

Imports

Passenger revenue: estimates of passenger fares paid to non-resident operators are derived mainly from the results of the International Passenger Survey which is described in the notes below on 'Travel'. A further allowance is made for on-board sales of goods and services.

Passenger fares paid to non-resident operators for fly-cruises, however, together with other expenditure by UK passengers on board nonresident shipping, is included, but not separately identified, in 'Travel' imports.

Freight: estimates of freight services on UK imports provided by non-resident operators are compiled as follows; the estimates of total freight services (provided by ALL operators) on the sea legs of UK imports of goods are taken as the starting point, as described in the methodological notes to table 2.4. Estimates of the element provided by UK operated ships, based on the data from the Chamber of Shipping are then deducted to obtain the nonresident operators' element which is then used in the transportation account. Charter payments cover payments for charters with crew.

Disbursements: disbursements abroad include payments for canal dues, the maintenance of shore establishments, port charges, agency fees, handling charges, crews' expenditure, pilotage and towage, light dues and other miscellaneous port expenditure abroad. Payments for bunkers, ships stores and other goods purchased are included within the trade in goods data.

\section{Air transport}

The exports of UK airlines comprise the carriage of non-resident passengers to, from or outside the UK, the carriage of UK exports of goods (but not imports - see 'Freight and the valuation of UK trade in goods', above) and cross-trades and the chartering of aircraft to non-residents. Exports also include airport charges and services purchased in the UK by foreign airlines. Purchases of fuel and other goods are included within trade in goods.

Imports include expenditure abroad by UK airlines on airport charges, crews' expenses, charter payments, etc. They also include payments to foreign airlines for the carriage etc. of UK imports of goods (but not exports) and of UK mail; and for the carriage of UK passengers on flights covered by tickets for journeys to or from the UK (the carriage of UK passengers on other non-resident flights is included under 'Travel').
The transactions of UK airlines are derived from returns supplied by the airlines to the Civil Aviation Authority.

\section{Exports}

Passenger revenue: this relates to all tickets sold outside the UK and used on UK aircraft, together with receipts from carrying passengers' excess baggage. An exercise by British Airways plc demonstrated that the value of tickets sold abroad to UK residents is roughly counterbalanced by sales in the UK to non-residents.

Freight: this consists of freight services on UK exports and the carriage of non-resident airmails, and is based on data supplied to the Civil Aviation Authority.

Disbursements and other revenue: these comprise expenditure in the UK by non-resident airlines on landing fees, other airport charges, handling charges, crews' expenses, office rentals and expenses, salaries and wages of staff at UK offices, commissions to agents and advertising. The estimates are based on returns from the Civil Aviation Authority, BAA plc and municipal airports on their receipts from non-resident airlines for air traffic control, landing fees and other airport charges; and survey information collected from large non-resident airlines operating in the UK on their other UK expenses. Purchases of fuel and other goods are included within trade in goods.

Also included are receipts from the charter or hire of aircraft, and gross receipts of sums due from non-resident airlines under pooling arrangements and for services such as consultancy and engine overhaul.

Imports

Passenger: the information on fares paid by UK passengers to non-resident airlines is derived from the International Passenger Survey; see notes on 'Travel' below.

Freight: estimates of non-resident airlines' freight on UK imports are derived by subtracting from the estimates of total freight on imports of goods arriving by air (see the methodological notes to table 2.4) the element provided by UK airlines, the residual being the freight services supplied by non-resident airlines. Other imports comprise payments to non-resident airlines for carrying UK airmails as reported by the Royal Mail Group to the Civil Aviation Authority.

Disbursements and other payments: disbursements abroad include airport landing fees, other airport charges, charter payments, crews' expenses, the operating costs of overseas offices, agents' commissions, advertising, settlements with non-resident airlines under pooling arrangements, and miscellaneous expenditure abroad. Purchases of fuel and other goods are included within trade in goods.

\section{Other Transport}

This covers the movement of passengers and freight, and other related transport services, by rail, road and pipeline.

Rail: this consists primarily of expenditure on fares and rail freight through the Channel tunnel. Passenger revenue estimates are based on numbers of passengers through the tunnel and average fare information. Estimates of rail freight through the tunnel are based on data provided by Le Shuttle and freight operators.

As the tunnel operators are a joint UK/French enterprise, half of passenger and freight transactions are taken to accrue to the UK part of the business. All tickets sold in France are assumed to be sold to non-UK residents (likewise, all tickets sold in the UK are assumed sold to UK residents). Of these, 50 per cent are assumed to accrue to the UK as they represent exports of rail transport services.

Road: exports comprise the earnings of UK road hauliers for the carriage outside the UK of UK exports of goods and the carriage within the exporting countries of UK imports (although such earnings from lorries leaving the UK via the Northern Ireland land boundary are only included from 2002). Estimates of numbers of journeys to various countries are derived from the International Road Haulage Survey, and rates for each journey are estimated from trade and other sources.

Imports include payments to all non-resident land transport operators for the carriage of UK imports of goods between the frontiers of the exporting countries and the foreign sea ports. Estimates are made by subtracting from the estimate of total freight on imports for land legs (see the methodological notes to table 2.4) an estimate of the element earned by UK operators (derived as for exports). Imports also include the earnings of non-resident road hauliers for carrying UK exports and imports within the UK, although estimates of the trade with the Republic of Ireland are only included from 1996. These are estimated from the statistics of ferry movements of foreign-registered lorries, average loads, and average lengths of haul within the UK and estimated freight rates. The disbursements abroad by UK road hauliers, and in the UK by non-resident road hauliers, are included within 'Travel'.

Pipeline: this covers the cost of transport of oil freight via undersea pipelines. Data are derived from a survey of North Sea Oil and Gas companies.

\section{Travel (Table 3.3)}

Travel covers goods and services provided to UK residents during trips of less than one year abroad (and provided to non-residents during similar trips in the UK). Transport to and from the UK is excluded and shown as passenger services under transportation (see above). Internal transport within the country being visited is included within travel.

A traveller is defined as an individual staying, for less than one year, in an economy of which he/she is not a resident. The exceptions are those military and diplomatic personnel, whose expenditure is recorded under government services. The one year rule does not apply to students and medical patients, who remain residents of their country of origin, even if the length of stay in another economy is more than a year.

The estimates are based primarily on the International Passenger Survey (IPS), which is a frontier sample survey which collects 
information on the expenditure of non-resident visitors leaving the UK and of UK residents returning from abroad. For package tourists, estimates of the transport elements are deducted from the reported total package costs. Estimates of the expenditure of UK residents visiting the Republic of Ireland and of Irish residents visiting the UK have been covered by the survey since the second quarter of 1999. Prior to this, data were derived from statistics published by the Irish Central Statistics Office.

\section{Business travel}

Business travel is divided into expenditure by seasonal and border workers (individuals who work some or all of the time in economic territories that differ from their resident households) and other business travel. Estimates are based on the IPS

\section{Personal trave}

Personal travel covers holidays, visits to friends and relatives, the expenditures of people visiting for education and health reasons and miscellaneous purposes. Visits for more than one purpose, where none is distinguished as the main purpose, are classified as other.

Education-related travel exports cover the tuition fees and other expenditure of students who are funded from abroad and studying in the UK (imports cover the expenditure of UK students studying abroad). The figures also include the fees and other expenditure of pupils in UK private schools and students at other colleges and language schools. Income received direct from abroad by examining bodies and correspondence course colleges is included within personal, cultural and recreational services

Fees and other expenditure paid by non-residen students for higher education are collected via a special IPS trailer which commenced in 1997.

Health-related travel covers the cost of medica and other expenses of those travelling abroad for medical treatment. Estimates are based on information supplied to the IPS

\section{Communication services (Table 3.4)}

Communication services covers two main categories of international transactions: telecommunications (telephone, telex, fax, email, satellite, cable and business network services) and postal and courier services. Information is obtained through the ONS International Trade in Services survey (ITIS) and direct from the Royal Mail Group.

\section{Insurance services (Table 3.5)}

Insurance services cover the provision of various types of insurance to non-residents by resident insurance enterprises and vice versa. Insurance services include freight insurance on goods being imported or exported, direct insurance (life, accident, fire, marine, aviation etc.) and reinsurance. The amounts recorded in the accounts reflect the service charge earned on the provision of insurance services. This is equal to net premiums from abroad (premiums less claims), plus property income attributed to policy holders, less the change in the reserves for foreign business, less foreign expenses. The figures for UK insurance companies' and brokers' underwriting activities are derived from annual inquiries conducted by ONS. Lloyd's of London underwriting activity is based on data supplied by the Corporation of Lloyd's; they also include receipts for management services provided to overseas members of Lloyd's syndicates.

\section{Life insurance and pension funds}

Life insurance covers underwriting services associated with long term policies. Data are collected in the ONS inquiry into insurance companies. Pension fund services include service charges relating to occupational and other pension schemes, but not compulsory social security services.

\section{Freight}

Treatment of freight insurance is consistent with the f.o.b. valuation of trade in goods (see 'Freight and the valuation of trade in goods' above). That is, non-resident importers pay for freight and insurance on journeys outside the UK. Where such services are provided by UK residents to foreign enterprises, this gives rise to a credit entry.

\section{Other direct insurance}

Other direct insurance covers accident and health insurance; marine, aviation and other transport insurance; fire and property insurance; pecuniary loss insurance; general liability insurance, and other (such as travel insurance and insurance related to loans and credit cards).

\section{Reinsurance}

Reinsurance represents subcontracting parts of risks, often to specialised operators, in return for a proportionate share of the premium income. Reinsurance may relate to packages which mix several types of risks. Exports of services are estimated as the balance of flows between resident reinsurers and non-resident insurers. Imports are estimated as the balance of flows between resident insurers and non-resident reinsurers.

\section{Auxiliary insurance services}

This covers insurance broking and agency services, insurance and pension consultancy services, evaluation and adjustment services, actuarial services, salvage administration services, regulatory and monitoring services on indemnities and recovery services. These are measured by net brokerage earnings on business written in foreign currencies, and sterling business known to relate to non-residents. The main source of information on auxiliary insurance services is the ITIS survey.

\section{Financial services (Table 3.6)}

Financial services cover financial intermediary and auxiliary services other than those of insurance companies and pension funds. They include services provided in connection with transactions in financial instruments, as well as other services related to financial activity, such as advisory custody and asset management services. These services may be charged for explicitly, for example through fees and commissions or implicitly, for example in the price spread offered in market making and foreign currency transactions. From the 2008 edition of Pink Book, financial services also include financial intermediation services indirectly measured (FISIM). FISIM represents the implicit charge for the services related to borrowing and lending that are provided by monetary financial institutions and paid for by the interest differential between borrowing and lending rather than by fees and commissions. FISIM is exported by UK monetary financial institutions and imported by UK insurance companies and pension funds, private nonfinancial corporations and households. Prior to the 2008 edition of the Pink Book, the data for FISIM imports and exports were implicitly included as part of earnings on other investment debits and credits within income. The upward revisions to trade in financial services from the inclusion of FISIM are exactly offset by revisions to investment income so there is no effect on the current balance.

Estimates of financial services are based on returns from the Bank of England (for banks), ITIS, ONS's security dealers survey and directly from other sources including the Baltic Exchange.

From the 2001 edition of the Pink Book, the service earnings of financial institutions are presented on a gross exports and imports basis. This treatment is consistent with the BPM5 edition of the accounts. Trade in services transactions covered by type of financial institution are detailed below

Monetary financial institutions (banks and building societies)

This covers UK banking services giving rise to:

- commissions for credit and bill transactions such as advising, opening and confirming documentary credits, collection of bills, etc

- financial intermediation services indirectly measured (FISIM)

- spread earnings (net service earnings through spreads on market making) including those on transactions in foreign exchange, securities and derivatives

- fees and commissions on foreign exchange dealing

- commission on new issues of securities investment management and securities transactions

- commission on derivatives transactions

- banking charges, income arising from lending activities, fees and commissions in respect of current account operations, overdraft facilities, executor and trustee services, guarantees, securities transactions and similar services

Estimates are based on inquiries carried out annually from 1986 to 1990 and for some earlier years. A quarterly survey was run in 1991. A new survey was introduced in 1992 to collect data on UK banks' current account transactions including services. A further new survey was introduced in 2004, which enabled 
the collection of spread earnings on foreign exchange, securities and derivatives transactions - the data prior to 2004 is estimated by the Bank of England largely on the basis of information on the volumes of transactions and movements in spreads. The survey is completed quarterly by a selected sample of banks and annually by the full UK banking population.

FISIM is calculated by assuming the existence of an interest rate that represents the pure costs of borrowing funds, known as the reference rate. When monetary financial institutions lend money, FISIM is the difference between the interest they actually charge on the loan and the amount that would be charged if this reference rate were used. When financial institutions accept deposits (or borrow money), FISIM is the difference between the amount of interest they actually pay on the deposit (or loan) and the amount that would be paid if the reference rate were used. Exports of FISIM from 1992 onwards have been estimated by the Bank of England based on survey information relating to UK banks' balance sheet data for loans and deposits with non-residents and their interest receipts and payments on loans and deposits with nonresidents. The reference rate used in these calculations is the average of the implied rates of return for loans and deposits. The implied rates of return are calculated by dividing the annualised amounts of interest paid or received in a quarter by the balance sheet level. FISIM on loans is calculated by multiplying the balance sheet level for loans by the quarterly reference rate and subtracting the result from the actual interest receipts on loans. FISIM on deposits is calculated by subtracting the actual interest paid on deposits from the result of multiplying the balance sheet level for deposits by the quarterly reference rate. Separate reference rates and FISIM estimates are calculated for sterling and foreign currency loans and deposits. As the information on interest receipts and payments with non-residents is not available before 1992 exports of FISIM have been estimated by ONS using balance sheet levels and interest rates based on LIBOR and the spread between implied rates of return on loans and deposits in the period for which data is available.

\section{Fund management companies}

From 2001, information on investment management fees and fees generated from advisory and other related functions has been collected via the ITIS survey. Earlier estimates were derived from a survey of companies whose main activity is fund management. Earnings are net of any foreign expenses by the institutions concerned. They exclude earnings of insurance companies, which are covered by separate returns made to ONS (see above, under 'Insurance Services').

\section{Securities Dealers}

The earnings of securities dealers are derived from a survey run by ONS. From the 1998 edition of the Pink Book, security dealers' spread earnings (service earnings through market making activities) are included as part of securities dealers' overseas earnings. This treatment is consistent with the domestic accounts as described in the European System of Accounts (1995). Estimates of these spread earnings are based on information on acquisitions and realisations of various classes of securities derived from ONS inquiries, together with the bid and offer prices for certain international bonds.

\section{Baltic Exchange}

This covers the brokerage and other service earnings of members of the Exchange for chartering, sales and purchases of ships and aircraft and other associated activities. Estimates are based on a survey of Exchange members.

\section{Other}

This includes commissions etc. received from abroad by UK residents (other than banks and oil companies, whose earnings are included elsewhere) for dealings in physical goods and in futures and options contracts. From 1990 to 2004 ONS carried out an annual survey of dealers in physical commodities. This data is now collected via the ITIS survey. The foreign earnings of financial futures and options dealers are assumed to have moved in line with the corresponding total earnings of such dealers reported in statutory returns to supervisory bodies.

This component also includes those financial services not included elsewhere, including financial service transactions (exports and imports) picked up from the ITIS survey, service charges on purchases of International Monetary Fund resources and estimates of imports of net spread earnings, which are based on the UK's share of world turnover data for cross-border foreign exchange and derivatives transactions and the UK's share of global imports of financial services.

Imports of FISIM are included under this section as well. Estimates are made for imports of FISIM by UK insurance companies and pension funds, non-financial corporations and households. These estimates are based on Bank for International Settlements (BIS) balance sheet data for UK private sector loans from and deposits with non resident banks, described in more detail in the methodological notes for tables 8.7 and 8.8. FISIM is calculated separately for each sector's loans and deposits by multiplying the sectorised balance sheet data from BIS by a fixed margin, which represents the difference between the reference rate and the interest rate paid or received on loans or deposits. The margins used are based on the margins observed in the calculation of exports.

\section{Computer and information services (Table 3.7)}

Computer and information services cover computer, news agency and other information provision-related service transactions. Examples of these services include data processing: hardware consultancy; software implementation; maintenance and repair of computers and peripheral equipment; the provision of news, photographs and feature articles to the media; database development, storage and dissemination both through the internet and through magnetic, optical or printed media; and direct, non-bulk subscriptions to newspapers and periodicals. Information is obtained from the ITIS survey. Excluded from computer services are the provision of packaged non-customised software on magnetic media, which are included in trade in goods.

\section{Royalties and license fees (Table 3.8)}

Royalties and licence fees cover the exchange of payments and receipts for the authorised use of intangible, non-produced, non-financial assets and proprietary rights (such as patents, copyrights, trademarks, industrial processes, franchises etc.) and with the use, through licensing agreements, of produced originals or prototypes (such as manuscripts and films).

The heading includes royalties, licenses to use patents, trade marks, designs, copyrights, etc.; manufacturing rights and the use of technical 'know-how'; amounts payable or receivable in respect of mineral royalties; and royalties on printed matter, sound recordings and performing rights. Data are obtained through the ITIS survey. Film royalties from the ONS Films and TV inquiry are also included. Royalties incorporated in the contract prices of UK exports and imports of goods are recorded under 'Trade in Goods'. The outright sale of a copyright is treated as a sale of a non-produced, non-financial asset and is recorded within the Capital Account (table 6.1).

\section{Other business services}

\section{(Table 3.9)}

'Other business services' covers a range of services including merchanting and other traderelated services, operational leasing (rental) without operators and miscellaneous business, professional and technical services.

\section{Merchanting and other trade related} services

Merchanting is defined as the purchase of a good by a resident from a non-resident and the subsequent resale of the good to another nonresident, without the good entering the compiling economy. The difference between the purchase and sale price is recorded as the value of merchanting services provided. Other traderelated services cover commissions on crossborder goods and service transactions paid to, for example, merchants, commodity brokers, commission agents and auction houses.

Estimates of the net profits of UK firms from third country trade in goods are derived from ONS surveys. From 1990 to 2004 ONS carried out a specific sample survey of export houses, but information from these institutions is now collected via the ITIS survey, which has always collected information from other institutions on merchanting and trade related services. This component also covers fees charged for ship classifications and other related services, including information supplied by Lloyd's Register of Shipping.

\section{Operational leasing}

Operational leasing covers leasing (other than financial leasing) and charters of ships, aircraft 
and other transportation equipment without crews. Operational leasing data are derived from the ITIS survey and from the Chamber of Shipping

\section{Miscellaneous business, professional} and technical services

Miscellaneous business, professional and technical services include legal, accounting, management consulting, recruitment and training and public relations; advertising and market research and development; architectural, engineering and other technical services; agricultural, mining and on-site processing services associated with agricultural crops (protection against disease or insects), forestry, mining (analysis of ores) etc.; and other services such as placement of personnel, security and investigative services, translation, photographic etc. This item includes data from a number of different data sources, the most important of which is the ITIS survey.

Estimates of the earnings of solicitors are based on surveys held in respect of 1980 and annually since 1986 by the Law Society (in which amounts forwarded to barristers are included). From the 2000 edition of Pink Book, earnings of solicitors are collected as part of the ITIS survey. Other legal services also included estimates of the overseas earnings of UK barristers as supplied by the Commercial Bar Association.

Estimates of banks' and securities dealers' nonfinancial service transactions appear in the other business services account.

\section{Personal, cultural and}

\section{recreational services (Table 3.10)}

Personal, cultural and recreational services are divided into audio-visual and related services and other. The first category covers services and associated fees relating to the production of motion pictures (on film or video tape), radio and television programmes (live or on tape), and musical recordings. It includes rentals, fees received by actors, directors, producers etc. The second category covers all other personal, cultural and recreational services including those associated with museums, libraries, archives, provision of correspondence courses by teachers or doctors etc. Income received direct from abroad by examining bodies and correspondence course colleges is also included. Most of the information is obtained from the ITIS survey but there is a separate ONS inquiry for the film and television industry.

\section{Government services (Table 3.11)}

Government services include all transactions by embassies, consulates, military units and defence agencies with residents of staff, military personnel etc. in the economies in which they are located. Other services included are transactions by other official entities such as aid missions and services, government tourist information and promotion offices, and the provision of joint military arrangements and peacekeeping forces (for example, United Nations). Information comes directly from government departments (including the Ministry of Defence and the Foreign and Commonwealth
Office), foreign embassies and United States Air Force bases in the UK.

\section{Exports}

Expenditure by foreign embassies/ consulates in the UK: this comprises the cost of operating and maintaining Commonwealth High Commission offices, foreign embassies and consulates in the UK, including the personal expenditure of diplomatic staff, but excluding the salaries of locally engaged staff, which are included within income; and similar expenditure by the UK offices of non-territorial organisations. In 1993 ONS conducted an inquiry to all high commission offices, embassies, consulates and international organisations in the UK. This figure has been updated for subsequent years using information obtained from several key high commissions and embassies and information on the number of diplomats in the UK.

Military units and agencies: this includes expenditure by the United States Air Force (USAF) in the UK (excluding the pay of locally engaged staff which is included within compensation of employees), together with receipts for services provided by UK military units in the UK and elsewhere to non-residents, such as military training schemes, which is sourced from the Defence Analytical Services Agency (DASA)

European Union institutions exports: these are services of the UK Government in collecting the UK contributions to the EU Budget, and services provided at the site of the EU's Joint European Torus project in Oxfordshire.

Other: this comprises goods and services which the government provides to non-residents under its economic aid programmes (these are offset under 'Bilateral aid' transfer debits) and miscellaneous goods and services supplied by the UK Government to foreign countries, including the reimbursement from other member states of the EU for treatment given by the National Health Service to their nationals.

Imports

Expenditure abroad by UK embassies and consulates: goods and services provided by local residents to UK embassies, High Commission offices, Consulates and the British Council account for most of this heading. It also includes the goods and services provided by local residents to UK diplomatic and other nonmilitary personnel stationed abroad, excluding the salaries of locally engaged staff. The source for this information is the Foreign and Commonwealth Office.

Expenditure abroad by UK military units and agencies: this includes expenditure on food, equipment, fuel and services purchased locally. These items are recorded partly on a net basis - that is, after deducting receipts arising locally. The source for this information is DASA.

Other: this includes goods and services provided by local residents to the UK

Government, excluding military and diplomatic expenditure. It covers expenditure abroad of the British Council and the reimbursement to other member states of the EU for medical treatment given to UK nationals.

\section{References}

United Kingdom Trade in Services, UKA1

UKA1 has been discontinued as a separate publication. All of the tables that were in Section A of UKA1 are now included in the Pink Book. New tables that were formerly in UKA1 but not in the Pink Book have been added to chapter 9 . The tables that were formerly in Sections $B$ and $C$ of UKA1 are now in a web-only publication which focuses on the results of the ITIS survey.

Old editions of UKA1 can be found at the following web address: www.statistics.gov.uk/ StatBase/Product.asp? vlnk=3343\&Pos= \&ColRank=1\&Rank=256

The publication containing the ITIS survey results can be found at the following web address:

www.statistics.gov.uk/StatBase/Product.asp? vlnk=14407\&Pos $=1 \&$ ColRank=2\&Rank=240

\section{Sea transport}

An annual analysis describing the international activities of the UK shipping industry is published by the Department for Transport, in Transport Statistics Great Britain (The Stationery Office).

Transport Statistics Great Britain, 2007 edition can be found at: www.dft.gov.uk/pgr/statistics/ datatablespublications/tsgb/

\section{Air transport}

Information relating to passenger expenditure is published by the Civil Aviation Authority in CAA Monthly and Annual Statistics.

CAA statistics are available at: www.caa co.uk/ default.aspx ? catid $=80$ \&pagetype $=90$

Travel

Details are published regularly in National Statistics monthly First Releases and quarterly Business Monitors (MQ6), both titled Overseas Travel and Tourism, and in the annual publication Travel Trends.

Overseas Travel and Tourism First Releases can be found at: www.statistics.gov.uk/StatBase/Product. asp? vlnk=8168\&Pos =1 \&Co|Rank=1\&Rank=192

MQ6 can be found at: www.statistics.gov.uk/ StatBase/Product. asp?vlnk=1905\&Pos= \&ColRank=1\&Rank=192

Travel Trends can be found at: www.statistics. gov.uk/Statbase/Product.asp?vlnk=1391

\section{Income (Chapter 4)}

The income account covers compensation of employees and investment income. For compensation of employees, estimates for total credits, debits and the balance appear at table 4.1 but no detailed breakdown of the account is available. Investment income is broken down into five main categories; direct investment, portfolio investment, financial derivatives, other investment, and reserve assets.

\section{Compensation of employees}

\section{(Table 4.1)}

Compensation of employees comprises wages, salaries, and other benefits paid by employers, in 
cash or in kind, to individuals who work in economies other than those in which they are residents. Employees, in this context, include seasonal or other short term workers (who stay for less than one year) and workers who cross international borders to get to their regular place of work. Compensation of employees also includes pay received by local (host country) staff of embassies, international organisations, consulates and military bases as such entities are considered non-resident of the host economy.

Personal expenditure made by non-resident seasonal and border workers in the economies in which they are employed is recorded under travel within trade in services. Wages and salaries are recorded gross, with taxes paid recorded under current transfers.

\section{Credits}

There are three components:

- Wages, salaries and other benefits earned by UK seasonal and border workers, together with employers' contributions. These are estimated using data from the International Passenger Survey on the number of UK resident seasonal and border workers working abroad and average earnings data

- Wages and salaries earned by UK employees in US military bases in the UK. Information has been supplied to ONS by US military bases

- Wages and salaries earned by UK employees of foreign embassies in the UK. In 1993, ONS conducted an inquiry to all high commission offices, embassies, consulates and international organisations in the UK, asking for information on expenditure - including that on locally employed staff. This figure has been updated for subsequent years using information from a small sample of key embassies

Debits

There are two components:

- Wages, salaries and other benefits earned by non-resident workers employed in the UK for less than one year. These are estimated using data from the International Passenger Survey on the number of foreign resident seasonal and border workers working in the UK and average earnings data

- Wages, salaries and other benefits earned by foreign workers working in UK embassies and military bases abroad. Information on pay of locally engaged staff in UK embassies and military bases abroad is obtained from HM Treasury's Combined Online Information System (COINS), the Foreign and Commonwealth Office (FCO) and the Ministry of Defence (MOD)

\section{International investment (Chapters 4, 7 and 8)}

International investment comprises investment between resident and non-resident economies. Five functional categories of investment are distinguished in the international investment accounts:

- Direct investment

\section{- Portfolio investment \\ - Financial derivatives \\ - Other investment \\ - Reserve assets}

The international investment accounts measure investment income (chapter 4), transactions in financial assets and liabilities (chapter 7) and the international investment position (chapter 8).

\section{Investment income (Chapter 4)}

The investment income account covers earnings (for example, profits, dividends and interest payments and receipts) arising from foreign investment in financial assets and liabilities. Credits are the earnings of UK residents from their investments abroad and other foreign assets. Debits are the earnings of foreign residents from their investments and funds held in the UK and other UK liabilities. The flow of investment is recorded separately from the earnings in the Financial Account, although reinvested earnings of companies with foreign affiliates are a component of both. The total value of UK assets and liabilities held at any time is also recorded separately under the International Investment Position. The presentation of these three sections is almost identical, although there are small differences in coverage in some cases, mainly because complete information is not available for all items.

Earnings on the credit side of the account cover such items as interest on UK residents' deposits with banks abroad, profits earned by UK companies from their foreign affiliates, and dividends and interest received by UK investors on their portfolio investments in foreign companies' securities, etc. Similarly, debits cover earnings by foreign investors on deposits held with UK banks, profits of foreign companies from their investments in their affiliates in the UK, and dividends and interest paid to foreign investors on their holdings of UK bonds and shares, including British government stocks, etc.

Earnings on assets and liabilities are defined to include all profits earned and interest and dividends paid to UK residents from nonresidents or to non-residents by UK residents. They are, where possible, measured net of income or corporation taxes payable without penalty during the recording period by the enterprise to the economy in which that enterprise operates and, in the case of profits, after allowing for depreciation. Dividends are recorded when they are paid (on a cash basis), whereas interest is recorded on an accruals basis.

Profits and dividends include the (credit) earnings from foreign affiliates of UK registered companies and the (debit) earnings of profits and dividends by UK-based affiliates of foreignbased companies. Conceptually, stock appreciation and other holding gains and losses should be excluded from the income flows entered in the balance of payments accounts, because they represent only valuation changes. However, data on these are included in banking sector statistics provided by the Bank of England. Profits retained abroad by foreign affiliates or retained in the UK by affiliates of foreign companies are included in the flows of earnings and offset in the financial account. All interest flows between UK residents and nonresidents are in principle included.

Interest on loans extended by and deposits with UK banks is now presented net of FISIM (Financial Intermediation Services Indirectly Measured). Likewise, UK non-bank loans from and deposits with banks abroad are also presented net of FISIM. FISIM is an estimate of the value of the services provided by financial intermediaries, such as banks, for which no explicit charges are made; instead these services are paid for as part of the margin between rates applied to savers and borrowers. The supposition is that savers would receive a higher interest rate and borrowers pay a lower interest rate if all financial services had explicit charges. FISIM received by UK banks is now recorded as an export of financial services while FISIM paid by UK-non-banks is now recorded as an import of financial services. Information on the estimation of FISIM is included in the methodological notes for Trade in Services.

\section{Financial account (Chapter 7)}

The financial account covers transactions which result in a change of ownership of financial assets and liabilities between UK residents and non-residents. The financial account is broken down into five main categories: direct investment, portfolio investment, financial derivatives, other investment, and reserve assets.

In the balance of payments accounts, the term 'investment' has a wide coverage. It refers not only to the creation of physical assets but also, for example, to the purchase (or sale) of paper assets, such as shares, bonds and other securities. Investment also covers the financing of trade movements and other financial transactions between related companies in the UK and abroad. These 'other financial transactions' consist mainly of borrowing and lending by banks, both transactions by UK banks with non-residents and transactions of banks abroad with UK residents. Such borrowing and lending may be associated with UK trade in goods. For example, a non-resident may borrow from a UK bank to pay a UK exporter; alternatively he may use money already on deposit with the bank. Such borrowing or use of deposits will be included in the appropriate item in the financial account offsetting the entry under trade in goods.

Banking transactions may also arise from the financing of other financial transactions. For example, a UK company may borrow from a foreign bank in order to finance investment ('direct investment') in one of its subsidiary companies abroad. In this case, both the bank borrowing and the investment would be recorded in this section of the accounts and the two entries would offset each other; the investment would increase UK assets abroad while the borrowing would increase UK liabilities to foreign residents.

The total value of assets and liabilities held at the end of each year is recorded separately under the International Investment Position (see chapter 8) and the income earned from them is recorded under investment income within the 
income account (see chapter 4). The presentations of these sections are almost identical although there are small differences in coverage in some cases, mainly because full information is not available for all items. The financial account tables appearing at chapter 7 show net debits (UK assets) above net credits (UK liabilities), in order to allow easier read across with the investment income and international investment position tables which appear at chapters 4 and 8

\section{International investment position (Chapter 8)}

The international investment position brings together the available estimates of the levels of identified UK external assets (foreign assets owned by UK residents) and identified UK external liabilities (UK assets owned by foreign residents) at the end of each calendar year.

The presentation of the international investment position is almost identical to the presentation of investment income, within the income account (see chapter 4) and the financial account (see chapter 7 ) although there are small differences in coverage in some cases, mainly because full information is not available for all items.

Changes in balance sheet levels will reflect not only transactions in the corresponding assets and liabilities but also changes in valuation and certain other changes. Changes in valuation will occur in the following circumstances:

- where assets and liabilities are denominated in foreign currencies, their equivalent sterling value may change because of changes in foreign exchange rates

- where assets and liabilities are regularly bought and sold (for example, British government stocks, UK and foreign company securities), the current market value may be different from the value at which they were acquired

- where the holders of assets and liabilities change their values in preparing their accounts to reflect what is thought to represent the current position (for example, bad debts may be written off and direct investment assets may be written up or down in the books of the investing company)

In addition to changes in the valuation of identical underlying assets and liabilities, changes in recorded levels of external assets and liabilities will also reflect some changes in coverage which introduce discontinuities in the series.

\section{Assessment of the international} investment position

Because of the very varied data sources used to derive the estimates for the international investment position, there are some inconsistencies between the different figures in the tables, resulting particularly from different methods of valuation. Wherever possible, figures are at market values. However, for significant items such as direct investment, the figures are at own funds of book value and are subject to all the limitations of data taken from accounting balance sheets as a reflection of current market values. To the extent that the conventional valuation basis for direct investment is own funds at book value, or, in the case of banks, often historical cost values, an up-to-date valuation closer to market values is likely to be higher.

In addition, some assets and liabilities are measured very imperfectly (for example, for a number of items, levels of assets and liabilities are not directly reported but derived from cumulating recent identified transactions and allowing for estimated valuation changes). The balance between the estimates of identified external assets and liabilities has always been an imperfect measure of the UK's debtor/creditor position with the rest of the world.

To the extent that net errors and omissions reflect unrecorded or misrecorded financial transactions, the external balance sheet will tend to fail to capture the corresponding levels of assets and liabilities, although much will depend on the categories of assets and liabilities concerned:

- where both levels and transactions are reported (for example, portfolio investment by most financial intermediaries), there may be similar deficiencies to estimates of both levels and transactions, although levels may tend to be more accurate to the extent they are derived from annual accounting data

- where only levels are reported and transactions are derived from changes in levels, allowing as far as possible for valuation changes, (for example, non-portfolio transactions of UK and foreign banks), there may be errors in the estimates of transactions (for example, in allowing for valuation changes) with no corresponding error in levels

- where only transactions are reported and levels are calculated by cumulating transactions and allowing for valuation changes (for example, inward portfolio investment in UK company bonds), errors in recording transactions will lead to corresponding errors in levels. Thus if part of the net errors and omissions represents such missing portfolio investment inflows, the identified net assets figures will be overstated

\section{Allocation of Special Drawing Rights}

These are issued to the UK by the IMF but are not regarded by them as a liability of the UK and do not form part of total external liabilities in this table.

\section{Direct investment}

\section{Introduction}

A direct investment relationship exists if the investor has an equity holding in an enterprise, resident in another country, of 10 per cent or more of the ordinary shares or voting stock. The direct investment relationship extends to branches, subsidiaries and to other businesses where the enterprise has significant shareholding. Equity investment in which the investor does not have an effective voice in the management of the enterprise (that is, the investor has less than 10 per cent of the voting shares) is regarded as portfolio investment. The estimates of direct investment include the investor's share of the reinvested earnings of the subsidiary or associated company, the net acquisition of equity capital, changes in intercompany accounts and changes in branch/head office indebtedness. Further details are given in the Glossary.

\section{Income (Tables 4.3 and 4.4)}

Direct investment earnings include interest on loan capital, profits from branches or other unincorporated enterprises abroad and the direct investor's share of the profits of subsidiary and associate companies. It includes the direct investor's portion of reinvested earnings, which is also treated as a new investment flow out of the parent's country into the affiliate's and appears in the financial account (table 7.3) as an offsetting entry to the earnings one. Estimates of profits are made after providing for depreciation, the companies' own estimates of depreciation being used. Although depreciation is estimated at replacement cost in the national accounts, there is little doubt that the estimates in the balance of payments are, in the main, measured at historic cost (different treatments of depreciation result in different entries in the current and financial accounts, but the sum of the two entries will always be the same).

International reporting standards recommend that direct investment enterprises report their profits on a 'current operating performance' basis and not include any realised or unrealised holding gains/losses, exceptional items, writedowns or write-offs. This is generally the case with the exception of the profits of monetary financial institutions, which report to the Bank of England on an 'all inclusive basis' and include realised and unrealised holding gains/losses, write-downs or write-offs.

Refunds of tax made retrospectively under double-taxation agreements are included in the period when they were made rather than the earlier periods in which they could be deemed to have accrued. Dividend receipts and payments include subsidiaries payments of withholding $\operatorname{tax}$

Estimates for reinvested earnings are not collected separately but are derived by deducting dividends paid from total subsidiaries profits.

\section{Financial account (Tables 7.3 and 7.4)}

The components of the direct investment financial account comprise equity capital, reinvested earnings and other capital associated with inter-company debt transactions. Intercompany transactions between affiliated monetary financial institutions and between affiliated other financial institutions (for example, securities dealers) are limited to those associated with permanent debt. The usual inter-company deposits and other claims and liabilities associated with these financial institutions are reported under other investment.

International investment position (Tables 8.3 and 8.4)

The estimate of the international investment position relates to total net asset values 
attributable to investing companies, that is, book values of fixed assets less accumulated depreciation provisions plus current assets less current liabilities. The book values of direct investments are likely to be less than the values at written down replacement cost and less than the market values. There are no official estimates of the market value of UK direct investment assets and liabilities. However, research by Cliff Pratten (Department of Applied Economics, University of Cambridge) indicated that, on certain assumptions, the market value of UK direct investments abroad at end-1989 might be about double their book value, while the market value of foreign direct investment in the UK might be just under double their book values at the same point of time. However there are considerable uncertainties in making such estimates.

The comparison between transactions in the balance of payments account and changes in total assets and liabilities is not affected by allowances for depreciation of fixed assets as charged to the profit and loss account; such allowances are deducted before arriving at the earnings included in the current account, and the provision for depreciation is regarded as maintaining the total book value of the existing assets. Similarly, the comparison is unaffected by the treatment of reinvested earnings from direct investments, since these appear both in the current account as earnings and in the financial account as a flow of capital adding to the stock of assets. However, the values are affected by the treatment applied in their consolidated accounts by UK companies to value newly acquired foreign companies. Under both merger and acquisition accounting the increase in the net book value can be less than the net investment to complete the acquisition. The difference represents goodwill and the other costs associated with the transaction that are written off directly against reserves.

\section{Direct investment abroad by UK residents}

Monetary financial institutions (banks): information on the direct investment by UK registered banks in their foreign branches, subsidiaries and associates is collected by the Bank of England from a selection of banks quarterly which are, or have, a direct investment enterprise. This is supplemented by additional information from certain banks that only report to the Bank of England on an annual basis.

Insurance companies and other financial intermediaries: an annual inquiry forms the basis for estimates of direct investment by UK insurance companies and other financial intermediaries; these results are supplemented by a quarterly survey. Investment in foreign property by financial companies is also included here. They are estimated from the levels of such assets held by financial companies and information on their total income from abroad. In line with international standards, the investment of other financial intermediaries includes those of all holding companies.

Private non-financial and public corporations: information on direct investment by all private and public non-financial corporations is estimated from the results of ONS's annual direct investment inquiry. This inquiry covers a sample of UK companies that either have foreign affiliates or are affiliated to a foreign parent. Returns are imputed for companies which are not approached in the inquiry but which are known to have direct investment links. The estimates for the latest year are based on a quarterly inquiry with a smaller population sample. Results of the annual inquiry are available about twelve months after the end of the year and are published in a National Statistics First Release and in Business Monitor MA4

Copies of the FDI First Release can be found at: www.statistics.gov.uk/StatBase/Product.asp?vln $\mathrm{k}=728 \&$ Pos $=1 \&$ CoIRank=1\&Rank $=224$

Copies of the FDI Business Monitor can be found at: www.statistics.gov.uk/StatBase/Product.asp? vlnk=9614\&Pos $=1 \&$ ColRank $=1 \&$ Rank $=224$

Households: this comprises household sector investment in property abroad. Investment in property includes the ownership of 'second homes' located outside the UK. Estimates of property ownership are based on information from the Department for Communities and Local Government (DCLG)'s Survey of English Housing (SEH). The SEH collects information from English households on the number of properties owned outside the UK. These estimates have been grossed to include all UK households. Average dwelling prices are applied as well as an estimate of property rental. For more information on the latest methodology see the Economic Trends article:

www.statistics.gov.uk/CCI/article.asp? ID $=1176 \&$ Pos $=6 \&$ ColRank $=2 \&$ Rank $=224$

\section{Direct investment in the UK by foreign} residents

Estimates for direct investment in the UK are based on the same inquiries to banks, financial institutions and private non-financial corporations as direct investment abroad.

Households: limited information on property transactions was originally based on information obtained from the then Inland Revenue and on ONS estimates. From 2003, the Inland Revenue ceased to collect data, and from this point the data should be regarded as being of lower quality. ONS estimates are based on publicly reported property transactions.

\section{Portfolio investment}

\section{Introduction}

Portfolio investment comprises investment in either equity or debt securities that are not considered to have led to the acquisition of a foreign affiliate (that is, less than 10 per cent ownership) and so are classified as portfolio rather than direct investment. Portfolio investment is sub-divided into investment in equity or debt securities; debt securities are further sub-divided into investment in bonds and notes (long-term) and investment in money market instruments (short-term).

Income (Tables 4.5 and 4.6)

Earnings on equity securities consist of dividends received by investors on their holdings of shares of registered companies. Earnings on debt securities consists of interest received on investment in bonds and notes (government and municipal loan stock and bonds and notes of private and public corporations) and money market instruments (commercial paper, certificates of deposit, Treasury bills, etc.). Dividends are recorded on a paid basis and interest is recorded on an accrued basis.

\section{Financial account (Tables 7.5 and 7.6)}

Financial accounts transactions in equity securities comprise the acquisitions or disposals in the ordinary shares of registered companies. Transactions in bonds and notes consist of the acquisition and disposal of government and municipal loan stock, and bonds and notes of registered companies. Transactions in money investment comprise the acquisition and disposal of government short-term paper (Treasury bills), certificates of deposits, commercial paper, etc.).

\section{International investment position} (Tables 8.5 and 8.6)

As with investment income and the financial account, the international investment position is divided into investment in equity and debt securities with debt securities further subdivided into investment in bonds and notes and investment in money market instruments. Investment in both equity and debt securities are recorded at market value.

\section{Portfolio investment abroad by UK} residents

Monetary financial institutions (banks and building societies): estimates are derived from statutory inquiries conducted by the Bank of England. Prior to 2006, portfolio transactions by UK MFIs were based on reported transactions. From 2006 onwards, estimates of net transactions in both equity and debt securities by UK MFIs are derived from changes in reported balance sheets adjusted for both price and exchange rate effects. UK banks' earnings on portfolio investment abroad are collected on a quarterly basis by the Bank of England.

Insurance companies, pension funds and securities dealers: estimates are largely derived from quarterly ONS inquiries. These quarterly inquiries are supplemented by a more comprehensive annual inquiry.

Other financial intermediaries and private non-financial corporations: estimates are derived from survey-based asset levels to which rates of return on comparable assets shown by financial institutions are applied.

Households: estimates of investment by the household sector largely consist of investment by members of Lloyd's of London which are supplied annually by Lloyd's. They include portfolio investment income on funds which are held abroad to support business underwritten in those countries. Also included are estimates of investment in foreign equity securities acquired by UK households in exchange for their holdings of UK equities following an acquisition by a foreign direct investor. Typically, such acquisitions are funded by the issuance of shares by the investing company, rather than a cash payment. Significant levels of household ownership are most likely to exist when the UK 
company is a demutualised building society or privatised public utility.

\section{Portfolio investment in the UK by foreign residents}

As with portfolio investment abroad, portfolio investment in the UK is sub-divided into investment in equity securities and debt securities with investment in debt securities further subdivided into investment in bonds and notes and investment in money market instruments.

Equity securities

Prior to 2007, the main sources for estimates of new investment in UK equity securities were a range of statistical inquiries conducted by ONS Data were then adjusted to take account of total levels of foreign investment in shares as indicated by the results of ONS's biennial Share Ownership Survey. The Share Ownership Survey identifies the beneficial owner of listed UK equity securities held by both UK and foreign residents. Adjustments are made to exclude holdings of a direct investment nature and to establish the beneficial ownership of nominee share and third party share holdings. From 2007, new investment in UK equity securities by nonresidents is derived by residual. Non-resident investment in UK equity securities is obtained by assuming that any net transactions in UK equity securities not attributable to the domestic sectors of the UK (using all available data sources) are attributable to foreign residents.

Estimates of foreign earnings from UK equity securities consist of dividends paid to foreign holders of UK company ordinary shares. These estimates are calculated from Stock Exchange data on dividend payments, which are applied pro-rata to levels of non-resident holdings of UK shares derived from ONS's Share Ownership Surveys.

The latest Share Ownership Report, covering end-2006, was published by ONS in July 2007. Copies of the Share Ownership Report can be found at:

www.statistics.gov.uk/StatBase/Product.asp?vln $\mathrm{k}=930 \& \mathrm{Pos}=1 \&$ ColRank $=1 \&$ Rank $=272$

No precise sector breakdown is available and an assumption is made by ONS that non-resident holdings by sector of issuer are proportional to the overall equity liabilities of each sector.

\section{Debt securities - bonds and notes}

Non-resident investment in bonds and notes are comprised of those issued by HM Government and those issued by other sectors such as monetary financial institutions and private nonfinancial corporations.

Monetary financial institutions: estimates for non-resident investment in bonds and notes issued by UK banks and building societies stem from statistical surveys carried out by the Bank of England and ONS estimates. Information collected by the Bank of England for identified non-resident investment is supplemented by ONS estimates. ONS estimates allocate any residual investment to non-residents (for example, any securities not identified as being held by a specific sector are assumed to be held by non-residents). Earnings on bonds and notes issued by UK banks are reported by those banks to the Bank of England.
General government: investment in government bonds and notes comprises investment in British government securities (gilts) and other foreign currency bonds. Investment in British government securities by foreign central banks, international organisations and private foreign residents are measured from banking statistics and other Bank of England sources including the Central Gilts Office. Foreign earnings on British government stocks (gilts) are estimated from information on the levels outstanding and appropriate rates of interest. These earnings are calculated gross of UK income tax. Most gilts are issued by the UK Government at a discount to the redemption value. This is recorded as interest accruing over the lifetime of the gilt. Non-resident investment UK foreign currency bonds and notes issued by central government relates to bonds issued by HM Government (the latest of which is the $\$ 3$ billion 5-year eurobond issued in 2003). Information on the total issue of these foreign currency bonds is supplied by the Bank of England. Holdings by non-residents are once again derived as the residual of total securities in issue less those held by domestic sectors. Earnings are estimated on a pro-rata basis, proportional to the levels of investment.

Other sectors (other financial institutions and private non-financial corporations): foreign investment in bonds and notes issued by other sectors is primarily estimated on the residual basis where investment by non-residents is assumed to be the difference between total other sector bonds and notes in issues less those acquired or owned by UK residents. Information on total bonds and notes in issue and acquisition by UK residents is derived from the Bank of England and London Stock Exchange records of UK company bond issues, accumulated financial transactions, ONS surveys and price and exchange rate movements. Earnings are estimated on a pro-rata basis, proportional to the levels of investment.

Debt securities - money market instruments

Non-resident investment in UK money market instruments consist of foreign investment in UK treasury bills, certificates of deposit and commercial paper.

Monetary financial institutions: estimates for non-resident investment in money market instruments issued by UK banks and building societies stem from statistical surveys carried out by the Bank of England and ONS. Information collected by the Bank of England for identified non-resident investment is supplemented by ONS estimates. ONS estimates allocate any residual investment to non-residents (for example, any securities not identified as being held by a specific sector are assumed to be held by non-residents). Earnings on bonds and notes issued by UK banks are reported by those banks to the Bank of England.

General government: non-resident investment in government money market instruments comprises investment in UK treasury bills. Estimates for custody holdings held with UK banks are supplied by the Bank of England, and ONS allocates a fixed proportion of the residual (total issue less known acquisitions) to nonresidents. Earnings are estimated from information on the levels outstanding and appropriate rates of interest.
Other sectors (other financial institutions and private non-financial corporations): foreign investment in money market instruments issued by other sectors is primarily estimated on the residual basis where investment by nonresidents is assumed to be the difference between total other sector money market instruments in issues less those acquired or owned by UK residents. Information on total money market instruments in issue and acquisition by UK residents is derived from the Bank of England and London Stock Exchange records of UK company money market instruments issues, accumulated financial transactions, ONS surveys and price and exchange rate movements. Earnings are estimated on a pro-rata basis, proportional to the levels of investment.

\section{Financial derivatives}

Financial derivatives are defined as financial instruments that are linked to the price performance of an underlying asset and which involve the trading of financial risk. Examples of the underlying asset might include a financial instrument, commodity, bilateral foreign exchange rate, movement in stock index, or interest rate. Financial derivatives include options (on currencies, interest rates, commodities, indices, etc.), traded financial futures, warrants, currency and interest rate swaps, FRAs, and certain credit derivatives. The rationale for separate recording of derivatives contracts in the financial account is to keep the distinction between them and other transactions (for example, securities) to which they may be linked for hedging purposes. An article examining the use of derivatives in the UK accounts was published in the May 2005 edition of Economic Trends. It can be found at: www.statistics.gov.uk/downloads/theme_ economy/ET618.pdf

\section{Financial account (Table 7.1)}

Derivatives are valued at current market prices. Estimates for financial derivatives are currently unavailable except for net transactions by UK banks. Prior to 2005, the banks' transaction only covered net settlement receipts/payments on interest rate swaps and forward rate agreements. From 2005 onwards, the coverage is for all UK bank derivative transactions, data for which are supplied by the Bank of England.

\section{Balance sheets (Table FD)}

Data on UK banks' gross asset and liability positions in derivatives are collected quarterly by the Bank of England; no data are available prior to 1998. Data on securities dealers' assets and liabilities are collected by ONS; similarly there are no data available prior to 1998 .

Data published in table FD form supplementary information as estimates for financial derivatives have yet to be fully implemented in either the UK international investment position or in the UK's national accounts balance sheets. Work is continuing to validate and improve the estimates and obtain more information on the types of derivatives traded, and the underlying transactions. 


\section{Other investment}

\section{Introduction}

Other investment abroad is sub-divided into trade credit, loans, currency and deposits and other assets/liabilities.

Trade credit consists of claims and liabilities arising from the direct extension of credit by suppliers and buyers for goods and services transactions and advance payments for work to be undertaken or currently in progress. Lending activity to facilitate trade, including those loans underwritten by the Export Credit Guarantee Department (ECGD), are treated as loans and not trade credit within the accounts. Trade credit between related firms (that is, credit received or extended between a UK business and a foreign affiliate or parent company) is treated as an investment in the affiliate or parent company, and is therefore recorded under direct investment.

Loans comprise financial assets created by the direct lending of funds by a creditor (lender) to a debtor (borrower). This includes loans to finance trade, other loans and advances, financial leases and repurchase agreements.

Currency consists of notes and coins that are in circulation and commonly used to make payments. UK resident holdings of foreign currency are deemed a UK asset while non-resident holdings of Sterling are a UK liability. Deposits comprise both transferable (accessible on demand without penalty or restriction) and other deposits.

Other assets and liabilities comprise any other items that are neither trade-credit, loans nor deposits. The most notable other asset comprises the UK's subscriptions to international organisations while the most notable other liabilities are nonresidents' prepayments of premiums and reserves against outstanding insurance claims.

\section{Income (Tables 4.7 and 4.8)}

Income predominantly comprises the interest accruing on trade credit, loans or deposits. Interest is presented net of FISIM, which is recorded within exports and imports of financial services. 'Other income payments' includes an estimate of imputed income to foreign households from UK insurance companies' technical reserves and is recorded in the balance of payments because households are regarded as owning the net equity of pension funds and life assurance reserves; that is, the funds set aside for the purpose of satisfying the claims and benefits foreseen. The estimates are derived from data collected on ONS statistical inquiries.

\section{Financial account (Tables 7.7 and 7.8)}

The financial account records the drawing/ repayment of loans, the addition to or withdrawals from deposits, subscriptions to international organisations, debt forgiveness, adjustments for accrued interest and prepayments of premiums and reserves against outstanding insurance claims.

\section{International investment position} (Tables 8.7 and 8.8)

The international investment position presents total trade-credit, loans and deposits outstanding at end period. It also records total capital subscribed to the international organisations and levels of prepayments of premiums and reserves against outstanding insurance claims.

\section{Other investment abroad by UK} residents

Trade credit

At present only a minimal amount of data is recorded within trade credit. Some data previously recorded in this area have been reclassified as bank lending and are now within the loans data in other investment abroad. Other data are no longer suitable for inclusion and have been removed from the accounts, generally back to 1999 .

Loans

These are sub-divided into earnings on longterm loans and earnings on short-term loans; short-term loans are those which are repaid in full within one year.

Monetary financial institutions: MFI long-term loans comprise UK bank loans under the Export Credit Guarantee Department's guarantee. MF short-term loans comprise Sterling and foreign currency loans extended by UK banks and building societies. Information on loans extended by UK banks is collected by the Bank of England using a range of statistical inquiries while information on building society loans is supplied to the Bank of England by the Financial Services Authority. It is not possible to separate out UK banks' earnings on lending abroad from their earnings on deposits abroad. Estimates for earnings on such loans are therefore included indistinguishably within earnings on deposits (see below)

General government: government loans are all long-term and comprise inter-government loans. Estimates are sourced from information supplied by the Department for International Development.

Public corporations: public corporation loans are all long-term and are sourced from the Export Credit Guarantee Department and the Commonwealth Development Corporation.

\section{Currency and deposits}

\section{Currency}

Estimates for transactions in foreign notes and coin by the UK private sector other than monetary financial institutions are based on tourists' expenditure.

\section{Deposits}

Estimates comprise both transferable (accessible on demand without penalty or restriction) and other deposits held with abroad.

Monetary financial institutions: MFI deposits comprise UK banks' and building societies' Sterling and foreign currency deposits held with deposit taking institutions abroad. Information on deposits held abroad by UK banks is collected by the Bank of England using a range of statistical inquiries while information on building society deposits is supplied to the Bank of England by the Financial Services Authority. It is not possible to separate out UK banks earnings on lending abroad from their earnings on deposits abroad. Estimates for earnings on such loans are therefore included indistinguishably within earnings on deposits. Securities dealers: deposits held abroad by UK securities dealers are derived from quarterly ONS inquiries. Financial transactions and interest accrued are reported directly by the institutions while end period positions are estimated by ONS.

Other UK residents: estimates of other UK private sector deposits with banks abroad are derived from the banking statistics of countries in the Bank for International Settlements (BIS) reporting area (as defined in the Glossary). Endperiod positions are reported to the Bank of England, who in turn estimate net transactions. These data are then supplied to ONS. ONS then deducts deposits held abroad by UK securities dealers to avoid potential double counting. Interest on these deposits is then estimated by ONS using average quarterly levels and appropriate interest rates. Due to the limitations in the coverage of the BIS data, statistical adjustments have been applied to the financial flows data since 1994 to improve the overall coherence of the sector financial accounts. In order to maintain consistency between financial flows and balance sheet levels, corresponding coherence adjustments have been applied to the International Investment Position.

Transactions in non-monetary gold are included here and comprise net transactions in gold which are held as financial assets by listed institutions in the London Bullion Market (LBM) These estimates are currently derived from banking statistics collected by the Bank of England. The treatment of non-monetary gold is being reviewed as part of the worldwide process to revise the IMF Balance of Payments manual. The main proposal is that the concept of non-monetary gold would be replaced by two categories - allocated gold (a commodity) and unallocated gold (a financial instrument). UK BoP will continue current practice until the treatments defined in the revised manual are implemented.

Other assets

comprise any other items that are neither tradecredit, loans nor deposits.

Central government: this includes central government subscriptions to international organisations and covers capital subscriptions to international lending bodies other than the IMF, that is, regional development banks, the International Finance Corporation and the International Fund for Agricultural Development. Some transactions are in the form of noninterest-bearing promissory notes and are included in the accounts as the subscriptions fall due, irrespective of the time of encashment of the notes. The information is obtained from official records.

Monetary financial institutions and public corporations: estimates reflect UK banks' and the Export Credit Guarantee Department's (ECGD) debt forgiveness and offset the corresponding entry in the capital account. Information on debt forgiveness comes from the Bank of England and the ECGD.

Other sectors: these short-term assets largely relate to assets of UK insurance companies and pension funds and other financial intermediaries other than those classified under portfolio investment, estimates for which are obtained from ONS statistical inquiries. 
Other investment in the UK by nonresidents

\section{Trade credit}

At present only a minimal amount of data is recorded within trade credit. Some data previously recorded in this area has been reclassified as bank lending (see above), and is now within the loans data in other investment abroad. Other data are no longer suitable for inclusion and have been removed from the accounts, generally back to 1999 .

Loans

These are sub-divided into earnings on longterm loans and earnings on short-term loans; short-term loans are those which are repaid in full within one year.

General government and public corporations: general government loans are all long-term and comprise loans received by both central government and local authorities. Central government long-term loans such as Lend-Lease and the Lines of Credit were reported by HM Treasury. The final payment on these loans was made in 2005. Also included are the loans received under the Very Short-term Financing Facility (VSTFF) taken out during 1992 and repaid in 1993. Public corporations' borrowing directly from foreign residents under the exchange cover scheme is included. Repayments under the scheme by former public corporations that have since been privatised are included under repayments from central government, to whom their foreign debt was transferred following privatisation; such debt is known as novated debt. In recent years only local authorities have engaged in long-term borrowing from abroad; estimates are obtained from the Department for Communities and Local Government (DCLG).

Securities dealers: estimates for securities dealers' short-term loans from abroad are estimated from information collected through ONS inquiries. Since 1995 statistical adjustments have been applied to the data for securities dealers' short-term loans in order to improve the overall coherence of the sector financial accounts.

Other sectors: estimates of borrowing by other sectors are based on data reported to the Bank for International Settlements (BIS), and are generally confined to borrowing from commercial banks based within the BIS reporting area (see Glossary). End-period positions are reported to the Bank of England, who in turn estimate net transactions. These data are then supplied to ONS. ONS then deducts UK securities dealers' loans from banks abroad to avoid potential double counting. Interest on these loans is then estimated by ONS using average quarterly levels and appropriate interest rates. Due to the limitations in the coverage of the BIS data, statistical adjustments have been applied to the financial flows data since 1994 to improve the overall coherence of the sector financial accounts. In order to maintain consistency between financial flows and balance sheet levels, corresponding coherence adjustments have been applied to the International Investment Position. Additional information on borrowing from the European Investment Bank (EIB) is supplied directly to ONS on a quarterly basis by the EIB.
Currency and deposits

Currency

Estimates of transactions in sterling notes and coin by private foreign residents (other than monetary financial institutions) are based on ONS statistics of tourists' expenditure. While sterling bank notes are issued by the Bank of England, which is classified to monetary financial institutions, coins are issued by the Royal Mint, which is classified to the central government sector. In the absence of any separate data for notes and coin, it is assumed that notes make up 90 per cent of total notes and coin.

Deposits

Foreign deposits with UK monetary financial institutions are sub-divided into deposits with banks and deposits with building societies. Also included are deposit liabilities of central government.

Central government: deposit liabilities of UK central government include short-term intergovernment loans and transactions with nonresidents under minor government accounts in the form of changes in balances not attributable elsewhere in the accounts. Since 1973 this has consisted entirely of balances held by the Paymaster General on the European Union (EU) account.

Monetary financial institutions: it is not possible to separate out foreign deposits with UK banks from foreign loans to UK banks. The estimates for foreign loans to UK banks are therefore included indistinguishably within deposits. Within deposits with UK monetary financial institutions, estimates for sterling deposits are derived from banking statistics and include both current and deposit accounts. Foreign currency deposits comprise all external borrowing denominated in foreign currencies by UK banks (sometimes described as Euro currency transactions). They consist of changes in deposits with, and other lending to, UK banks from abroad. These transactions may be a reflection of (that is, the counterpart to) a variety of other foreign or domestic transactions by UK banks. These other transactions could be: foreign currency lending to UK residents (which are not balance of payments transactions); net purchases of foreign securities by the banks (which are included in direct or portfolio investment abroad as appropriate); any switching of banks' liabilities between foreign currencies (including gold) and sterling; or any change in the amount of foreign currency capital raised by banks. Estimates for foreign currency deposits with UK monetary financial institutions have been calculated from the end-quarter balance sheets as reported by all UK banks and building societies to the Bank of England. Adjustments are made to the reported changes in balance sheets to exclude revaluations resulting from changes in exchange rates. UK banks' income payments also include income payments associated with repurchase agreements and stock lending activities.

\section{Other liabilities}

These comprise any other items that are neither trade-credit, loans nor deposits.

Central government: these short-term liabilities largely consist of non-interest bearing notes, estimates for which are obtained from the Bank of England. Non-interest-bearing notes are issued by HM government and are held by international organisations.
Other sectors: long-term liabilities consist of net equity of foreign households in life assurance reserves and in pension funds and prepayments of premiums and reserves against outstanding claims which are recorded in the balance of payments because households are regarded as owning the net equity of pension funds and life assurance reserves; that is, the funds set aside for the purpose of satisfying the claims and benefits foreseen. The estimates are derived from data collected on ONS statistical inquiries. Short-term liabilities largely consist of additions to insurance companies' technical reserves, estimates for which are derived from ONS statistical inquiries.

\section{Reserve assets}

\section{Introduction}

Reserve assets comprise gold, convertible foreign currencies, IMF Special Drawing Rights (SDRs) and the UK's reserve position in the IMF. Currencies may be held in the form of financial instruments. From July 1979 convertible currencies also include European Currency Units acquired when 20 per cent of the gold and dollar holdings in the reserve assets were deposited on a swap basis with the European Monetary Co-operation Fund, the swap arrangement being renewed quarterly. As from January 1994 the swap was with the European Monetary Institute and as from January 1998 was with the European Central Bank. The swap arrangement was terminated in December 1998 All information on the reserve assets is recorded within the Exchange Equalisation Account by the Bank of England.

\section{Income (Table 4.1)}

Interest received on the official foreign exchange reserves and on the UK's holdings of Special Drawing Rights with the IMF and other remuneration received from the IMF (related to its holdings of sterling), is recorded within the Exchange Equalisation Account by the Bank of England.

\section{Financial account (Table 7.9)}

This item consists of the sterling equivalent, at current rates of exchange, of drawings on, and additions to the gold, convertible currencies and Special Drawing Rights (SDRs) held in the Exchange Equalisation Account; and of changes in the UK reserve position in the IMF.

\section{International investment position}

\section{(Table 8.9)}

Until 1999 securities were valued at historic cost and translated to sterling. Gold was valued at the ruling official price of 35 SDRs per fine ounce until end-1977 and at end-year market rates from end-1978 to end-1999. Since 2000, all reserve assets are valued at end-period market prices and exchange rates. SDRs and convertible currencies are valued throughout at closing middle market rates of exchange.

\section{Current transfers (Chapter 5)}

\section{Introduction}

Transfers represent the provision (or receipt) of an economic value by one party without directly 
receiving (or providing) a counterpart item of economic value. In plain terms a transaction representing 'something for nothing' or without a quid pro quo. Transfers can be in the form of money, or of goods or services provided without the expectation of payment. Transfers are broken down into current or capital transfers Capital transfers relate to the transfer of ownership of a fixed asset, or the forgiveness of a liability by a creditor, when no counterpart is received in return. Current transfers are all other types of transfer. Current transfers are subdivided into those made or received by central government and by other sectors. UK's contributions to and receipts from the European Union budget are recorded on a gross basis.

\section{Central government current transfers}

Central government transfers include receipts, contributions and subscriptions from or to European Union (EU) institutions and other international bodies, bilateral aid and military grants. Information mainly comes from government departments (HM Treasury, Foreign \& Commonwealth Office and Department for International Development).

\section{Credits}

These mainly comprise receipts of the UK central government from EU institutions, taxes on income, and social contributions paid by nonresident workers.

Current taxes on income and wealth: these are the receipts of the UK Government from taxes on the incomes of non-resident seasonal and border workers working in the UK (the incomes themselves are recorded as compensation of employees) and withholding taxes paid abroad by UK direct investment corporations. The former are estimated on the basis of the compensation of employees information derived from the International Passenger Survey and the latter from ONS inquiries into foreign direct investment.

Social contributions: these represent social contributions paid to the UK National Insurance Fund by non-residents.

EU institutions: these receipts comprise the VAT Abatement and other smaller, miscellaneous EU receipts. From the 1998 edition of the Pink Book, the VAT Abatement is treated as a credit entry to the UK balance of payments, rather than netted off VAT-based contributions.

\section{Debits}

These comprise payments by the UK central government to international organisations and other non-residents.

Social Security benefits: these mainly consist of National Insurance Fund retirement and war pensions paid to foreign residents.

European Union institutions: these payments are mainly the central government part of the UK contribution to the EU budget. For more detailed information, please see the methodological notes to table 9.9.

Other international organisations: this includes contributions to the military budget of
NATO, contributions to the European Regional Development Fund and agencies of the United Nations to provide economic assistance to developing countries, and subscriptions to cover the administrative expenses of various other international bodies.

Bilateral Aid: this covers technical co-operation and non-project grants (project grants are included within capital transfers as they fund capital projects). Technical co-operation covers the provision of technical 'know-how' to developing and transitional countries either as qualified manpower or as facilities for the training of nationals of these countries. It is wholly-funded by the UK Government and is included as a credit in Trade in Services. Nonproject grants are cash grants to developing countries for use in financing imports and budgetary support, together with the value of goods and services provided by the UK Government as food aid or disaster relief.

Military Grants: these consist of cash grants for military purposes and the value of goods and services of a military nature provided without charge to foreign countries and international organisations by the UK Government.

\section{Other sectors' transfers}

Other sectors' transfers cover current taxes paid, receipts and payments to EU institutions, net non-life insurance premiums and claims, and other payments and receipts of households, including remittances.

\section{Credits}

Private social contributions: this consists of the actual social contributions paid by nonresidents to UK private pension schemes, plus the related imputed contribution supplement, less the related service charge. Data are sourced from ONS surveys to pension funds.

Receipts from EU institutions: comprise those paid out of the EU's Agricultural Guarantee Fund and Social Fund. They are treated as nongovernment transfers within the national accounts and balance of payments, as the UK Government acts only as an agent for the ultimate beneficiary of the transfer.

Net non-life insurance premiums: comprise the actual premiums received by UK insurance companies from non-residents plus the related imputed premium supplement, less the related insurance service charge. The sources for these data are ONS surveys of insurance corporations, which collect premiums by type of insurance product, and Lloyd's of London.

Net non-life insurance claims: these are based on information supplied to the International Trade in Services survey on insurance claims received from non-resident insurance companies.

Other receipts of households: consists of two main components:

- Remittances, which are current transfers in cash or in kind sent by households resident in foreign economies to households resident in the UK. These estimates are statistical projections mainly based on bilateral information on partner countries' remittance flows to the UK, where these are published or have been made available to ONS, or on the basis of entries in the IMF Balance of Payments yearbook, with fixed percentages of the total workers' remittances for certain countries assumed to go to the UK

- UK charities transfer receipts from abroad. These are based on information from a 1995 survey to charities

\section{Debits}

Current taxes on income: these are taxes on the incomes of UK seasonal and border workers (recorded as Compensation of employees) working abroad and withholding taxes paid abroad by UK direct investment corporations. The former are estimated on the basis of the compensation of employees information derived from the International Passenger Survey and the latter from ONS's inquiries into foreign direct investment.

Private social benefits: comprise private pensions paid abroad, plus the change in net equity in pension fund reserves of non-residents. The data source is the ONS survey of pension funds.

Payments to EU institutions: these comprise agricultural and sugar levies, customs duties and VAT-based contributions.

Net non-life insurance premiums: this covers premiums paid by UK companies to non-resident insurance companies collected via the International Trade in Services survey.

Net non-life insurance claims: this covers settlement of claims by UK insurance companies to non-resident claimants, which are regarded as a transfer debit. The total of claims equals the total of net premiums (service charges having been deducted), as the essential function of non-life insurance is to redistribute resources The sources for these data are ONS's surveys of insurance corporations, and Lloyd's of London.

Other payments of households: these include two main components:

- Remittances, which are current transfers in cash or in kind sent by UK households to households resident in foreign economies. In many cases these are sent by long-term migrant workers in the UK to friends or relatives still resident in their country of origin. Data were obtained from exchange control records until 1979. Estimates since 1979 are statistical projections mainly based on the exchange control data and also some bilateral information on partner countries' remittance flows to the UK. The projections also take account of information on the value of gifts of money and goods sent abroad by parcel post

- UK charities' transfers abroad. These are based on information from a 1995 survey to charities

\section{Capital account (Chapter 6)}

The capital account comprises two components: capital transfers and the acquisition/disposal of non-produced, non-financial assets. 


\section{Capital Transfers}

Capital transfers are those involving transfers of ownership of fixed assets, transfers of funds associated with the acquisition or disposal of fixed assets, and cancellation of liabilities by creditors without any counterparts being received in return. As with current transfers, they can be sub-divided into central government transfers and other sectors transfers. The main sources of information are government departments (Department for International Development and HM Treasury) and the Bank of England. Compensation payments from the EU related to the destruction of animals to combat BSE and foot and mouth disease are also included here.

\section{Central government capital transfers}

These consist of debt forgiveness and project grants (there are no receipts in recent years). Debits

Debt forgiveness is defined as the voluntary cancellation of debt between a creditor, in this case the UK Government, and a debtor in another country. Data are supplied by the Department for International Development. Project grants are cash grants to developing countries for the establishment of production and infrastructure facilities. Such transfers are distinguished from current transfers as they are conditional on the acquisition of fixed assets. Data are supplied by the Department for International Development.

\section{Other sectors capital transfers}

These include migrant's transfers, debt forgiveness and capital transfers from European Union Institutions.

Credits

Migrants' Transfers: these are recorded as being equal to the net worth of the migrants, as they arrive in the UK. Estimates are based on information on number of migrants and average assets being transferred as collected on the International Passenger Survey.

Transfers from EU Institutions: Regional Development Fund and Agricultural Fund for Regional Development receipts from the EU are assumed to be capital rather than current transfers as they relate to infrastructure projects. Data are supplied by HM Treasury. Other capital transfers include agricultural compensation scheme payments relating to the destruction of animals to combat BSE and Foot and Mouth Disease.

Debits

Migrants' transfers: these represent the net worth of emigrants as they leave the UK. Estimates are based on information on the number of migrants and average assets being transferred as supplied to the International Passenger Survey.

Debt forgiveness: this consists of nongovernment debt forgiveness by monetary financial institutions and public corporations. Data on monetary financial institutions is supplied by the Bank of England and data on public corporations is supplied by the Export Credit Guarantee Department.
Sales/Purchases of non-produced, nonfinancial assets

This heading covers intangibles such as patents, copyrights, franchises, leases and other transferable contracts, goodwill etc. and transactions involving tangible assets that may be used or needed for the production of goods and services but have not themselves been produced, such as land and sub-soil assets. The use of such assets is recorded under trade in services as royalties and license fees; only the outright purchase or sale of such assets is recorded in the capital account.

The International Trade in Services (ITIS) survey has collected information on the sale and purchase of copyrights, patents and transferable contracts from 1996. Such transactions are indistinguishable from other areas of the current account for years before 1996

\section{Geographical breakdown on the current account and International Investment Position (Chapters 9 and 10)}

\section{Introduction}

The geographical data is broadly consistent with level 2 of Eurostat's Vade Mecum (66 individual countries, nine geographical regions and five continents). Data for the European Union (EU) relate to the membership following the enlargement of 1 January 2007. EU Institutions are included in the EU aggregate and are excluded from the International Organisations total. Separate data for Belgium and Luxembourg are not available for periods before 1999. Data for China exclude Hong Kong, which is shown as an individual item.

\section{Reliability of estimates}

The United Kingdom's (UK) balance of payments accounts are primarily compiled on a global basis. Not all of the data sources used in preparing the accounts attempt to distinguish transactions on a full country basis, although the majority do. Where individual country information is not reported, estimates are made by using the geographical detail for a related category; for example, the geographical breakdown of financial assets and liabilities is used to allocate some components of investment income.

In addition to the imputation of geographical detail for some categories where the data are incomplete, there remains a margin of uncertainty regarding the accuracy of reported data by country. The finer the level of geographical detail sought the greater the likelihood of misallocation. Enterprises are encouraged to make their best estimates, when asked to report geographical data, but as country allocation may not be a crucial aspect of the information from which details are extracted, a significant degree of estimation may occur.

Given these conceptual and practical limitations, these estimates should be seen as a broad indication of the economic relationships between the UK and the rest of the world economies. They will be more reliable and meaningful in terms of broad geographical areas and major partner countries than for smaller partners. Estimates for recent years are currently more reliable than those for earlier years, since some data sources do not extend back over the whole published period.

\section{Approach for country allocation}

The following notes summarise the main criteria of country allocation adopted for the various categories of the current account. In general the figures are not likely to be consistent with those recorded by countries which allocate regional balance of payments estimates on a cash settlements basis. An analysis of UK asymmetries with its EU and US partners was published in the March 2005 edition of Economic Trends, which can be found at: www.statistics.gov.uk/ downloads/theme_economy/ET616.pdf

\section{Trade in goods}

Exports of goods are allocated to the country of destination; imports of goods are allocated according to the country of consignment. However, export figures from a country (A) to another country (B) may over-estimate the value of goods actually consumed in that country (B) if the importer forwards the goods on to another country (C), There are several reasons for this: 'the Rotterdam/Antwerp effect' (exports are properly attributed to the country where the port of discharge is located, following international convention, but are then re-exported to the country of final destination); other transit trade (goods passing straight through the country); and triangular trade (where goods are sold from member state $A$ to $B$ and on to $C$, but the goods move directly from A to C.) . 'The Rotterdam/ Antwerp effect' is a particular issue with the UK because of exports routed through Rotterdam in the Netherlands and Antwerp in Belgium. No information is available on the value of UK exports that are subsequently shipped on to other countries, although investigations are taking place. The principal data source for trade in goods is HMRC (see methodological chapter on Trade in Goods for more details).

\section{Trade in services}

The geographical breakdown of exports and imports of services are largely based on the existing sources of information for the global estimates, although there is some use of proxy information for some components. The change from an industry to a product-based presentation with the introduction of the fifth edition of the IMF Balance of Payments Manual in 1998, and the consequent change to data collection, means that data from 1996 onwards is largely based on reported geographical breakdowns of the new products. Earlier geographical estimates are based on the industry-based geographical breakdowns in the fourth edition of the IMF Balance of Payments Manual, adjusted to take the changes to the trade in services classification into account.

Sea transport: estimates relating to ships owned or chartered by UK operators are taken from inquiries carried out by the Chamber of Shipping. 
Geographical breakdowns of freight services on exports and cross trades are allocated using the ports at which the goods are unloaded. For nonresident operators' freight on UK imports, the nationality of the exporting country is used as a proxy to allocate the freight payments. The resulting proportions are used to calculate the shares of non-resident operators' disbursements in the UK. Disbursements abroad by UK operators are supplied annually by the Chamber of Shipping.

Passenger revenue export estimates are derived from information supplied annually by the Chamber of Shipping. Passenger revenue import estimates are based on assumptions about the likely markets for cruises and on other information relating to the movements of UK shipping.

Air transport: passenger revenue exports are based on information supplied to ONS by the Civil Aviation Authority, which gives the required country analysis of fares paid. Other transactions with foreign airlines are allocated by nationality of airline. Receipts by UK airlines from foreign passengers are allocated to the countries in which tickets are purchased. Freight services on UK imports earned by foreign airlines are allocated to the countries of consignment of the imports.

Other transport: rail passenger exports are based on assumptions of the likely nationality of channel tunnel users. Rail imports are allocated entirely to France. Estimates for road freight exports and imports are based on information supplied by the Road Haulage Association. This information includes details of the vehicles' load and country of destination or country of origin. Pipeline transport is based on those countries that are assumed to import / export North Sea oil and gas.

Travel: a detailed geographical split of travel expenditure, both exports and imports, are obtained from the International Passenger Survey. Allocation of expenditure of overseas visitors to the UK is by country of residence. UK residents' expenditures abroad are allocated to the country in which most time was spent, or, if this cannot be determined, the furthest country visited. As a result, expenditure in countries with appreciable numbers of transit tourists may be understated

Other services: data for communication, construction, computer and information, royalties, other business and personal services are largely based on information supplied to the ITIS survey, supplemented with information from Royal Mail, ONS's Film and Television inquiries and Lloyd's registry for shipping.

Insurance services: estimates are based on detailed geographical data provided by Lloyd's of London, as well as the ITIS survey for insurance imports provided to non-insurance institutions. The geographical split of trade in goods' imports is used as a proxy for freight insurance imports. Geographical splits for other insurance services are based on fixed weights.

Financial services: regular geographical information on gross flows is obtained from the Bank of England for banking services (including FISIM), and from the ITIS survey for financial service exports and imports from non-financial institutions. The geographical breakdown of non-bank financial corporation service exports are imputed using banking geographical data as a proxy.

Government services: for the major components, detailed geographical information on the location of those receiving or making payments is available from returns provided by the Ministry of Defence, Department for Work and Pensions, and the Foreign and Commonwealth Office. The United States Air Force has also provided data on expenditure of US Forces in the UK. Expenditure by foreign embassies and consulates in the UK is based on information supplied by some overseas embassies and statistical institutions, supplemented by information on numbers of accredited diplomats by country.

\section{Income}

Compensation of employees: estimates of the geographical breakdown of seasonal and border workers' earnings are based on information supplied to the International Passenger Survey. Figures for the earnings of locally engaged staff are based on information supplied by government departments.

\section{Investment income and International} Investment Position

Direct investment income: figures are based on the quarterly and annual foreign investment inquiries and include reinvested profits. Geographical information is based on the country of registration of the immediate foreign parent company and the location of the foreign affiliate, except for banks where the information relates to the country of residence of the ultimate owner (for inward investment) or the country of residence in which the direct investment enterprise is located.

Portfolio investment income: credits are the earnings accruing to UK residents from their investment in equities and debt securities, in the form of bonds and notes and money market instruments, issued by foreign institutions. Global estimates are derived from surveys of UK end-investors (banks, securities dealers, unit and investment trusts, insurance companies, pension funds and some non-financial companies).

Deriving a geographical breakdown of portfolio investment income flows has been one of the most problematic areas of Balance of Payments compilation. Portfolio investment income is particularly difficult to allocate correctly to the actual country owning or issuing the security, as the transactions are often made through financial intermediaries in a third country. However, with the launch and subsequent expansion of the IMF's Co-ordinated Portfolio Investment Survey (CPIS), an important new data source has become available. Participants in the CPIS collect a geographical breakdown of their portfolio investment assets, which are coordinated and disseminated by the IMF.

Data on the geographical breakdown of portfolio investment credits are derived from the UK's contribution to the CPIS exercise from 2001. For banks, Bank of England information on the geographical breakdown of levels is applied to the estimates of global earnings obtained by surveys of UK banks. Similarly for non-banks, a geographical breakdown of portfolio investment income is derived from the geographical breakdown of portfolio investment assets.

Information on the geographical breakdown of UK portfolio investment debits (dividends and interest payments made to overseas residents by issuers of UK securities), are based on other countries' participation in the CPIS exercise. The IMF acts as a central clearing house for the compilation of aggregate data from countries that have participated in the CPIS and disseminate the information to BoP compilers. These data can provide us with information on participating countries' holdings of UK issued equity and debt securities. For earlier years, surveys of share ownership are used to allocate portfolio holdings of UK equity securities and associated dividends by country of holder. For interest on holdings of debt securities, data derived from the CPIS exercises from 2001 onwards have been used to estimate the geographical breakdown.

Other investment income: gross interest flows between UK banks and the rest of the world are estimated by the Bank of England by allocating global interest receipts and payments in proportion to the corresponding levels of assets and liabilities of UK banks. Interest flows for UK non-bank deposits with, and borrowing from, banks in the BIS reporting area are allocated in proportion to the levels supplied by the BIS. The interest on reserve assets is estimated from official records. Figures for UK banks are used as proxies to estimate a country breakdown for the remaining components of earnings on other investment.

Adjustments applied to the global earnings on other investment to exclude the Channel Islands and the Isle of Man have been used to estimate other investment income between the UK and the offshore islands. These data are included within 'Other Europe'.

\section{Current transfers}

There are very few data sources for current transfers that allocate transactions on a country basis - these are outlined below. The geographical allocation of withholding taxes is based on the geographical allocation of inward and outward direct investment as published in Business Monitor MA4. The geographical allocation of insurance premiums is based on information supplied by Lloyd's of London. Data on EU transfers are provided by the Treasury, and the geographical allocation of social security and aid payments are supplied by the Department for Work and Pensions and the Department for International Development, respectively. Other geographical breakdowns are based on proxy data and global transfer estimates.

\section{UK official transactions with institutions of the EU (Table 9.9)}

This table presents all the official transactions between the UK Government and the 
Institutions of the European Union. The series are the same as those shown in table 12.1 of the Blue Book but the presentation here reflects Balance of Payments rather than National Accounts classification of transactions.

Some of the transfers are classified to Other sectors (rather than central government) as they are paid by or to non-government sectors; however they are still classified as official transactions because the money is collected from or paid to non-government sectors by the UK Government on behalf of the EU. The source for much of the data is HM Treasury (HMT), who are responsible for the UK's official transactions with the EU. These data represent the cash movements in and out of Government bank accounts for Transactions with the EU. Any divergences from this source - to accord with the reporting conventions required for Balance of Payments and National Accounts - are detailed below. The data sourced from HMT are also available in table 3 of the HMT White Paper on EU Finances found at the following web address: www.hm-treasury. gov.uk/documents/international_issues/eu_ information/int_eu_statefraud.cfm

\section{Credits}

\section{Exports of services}

This series represents the part of the import levies collected by the UK Government on behalf of the EU that the UK Government retains to cover the costs of collection. The percentage retained was 10 per cent up until 2000 and has been 25 per cent from 2001 onwards. It is treated as an export of a government service. The exports of services to EU Institutions series in table 9.3 differs from this one in that that series includes services provided to EU Institutions by UK private companies.

\section{Other sectors current transfers}

These largely comprise receipts from the Agricultural Guarantee Fund and the European Social Fund. The receipts from the Agricultural Guarantee Fund are classified as subsidies and are recorded on an accruals basis based on the subsidies paid to farmers by the Rural Payments Agency.

\section{Central government current transfers}

These mainly comprise the Fontainebleau Abatement but also include a small number of miscellaneous payments to EU institutions and research councils. Since 1984, the UK's third own resources (VAT-based) contribution to the EU budget has been abated in recognition of the relatively low level of its receipts, compared with its contributions to the Community Budget. Broadly, the UK receives a VAT abatement of its gross contributions equal to two-thirds of the difference between its unabated contribution and its receipts. This is deducted a year in arrears. Since the 1998 edition of the Pink Book, this abatement has been treated as a credit entry to the UK balance of payments rather than simply being netted off VAT-based contributions.

\section{Other sectors capital transfers}

In most years these consist entirely of receipts from the Agricultural Fund for Regional
Development and the European Regional Development Fund. Other capital transfers from EU institutions are payments to farmers under agricultural compensation schemes related to the destruction of animals during the BSE and Foot and Mouth disease outbreaks.

\section{Debits}

\section{Other sectors current transfers}

These comprise the UK's traditional own resource and third own resource contributions to the EU. The former are customs duties paid on a range of products imported from non-member states, and levies charged on the production of sugar to recover part of the costs of subsidising the export of surplus EU sugar on to the world market. EU third own resources are VAT-based contributions which represent a notional extra one per cent on the VAT base, but are capped at one-half of one per cent of Gross National Income (GNI), hence the adjustment to VAT contributions. Payments of both traditional and third own resource contributions are classified as taxes paid direct to the EU. Estimates are sourced from HMRC and are converted to an accruals basis using agreed methodologies.

\section{Central government current transfers}

This mainly consists of the UK Government's fourth own resource contribution. This is calculated as a fixed percentage of UK GNI, increased or rebated according to whether within the EU budget as a whole, expenditure exceeds or falls short of revenue. There are also a small number of miscellaneous payments to EU institutions under this heading

\section{Trade in Goods and Services} additional tables (Tables 9.10,

\subsection{1, 9.12, 9.13 and 9.14)}

Tables 9.10 and 9.11 show imports of services from and exports of services to selected partner countries broken down by the eleven broad categories of services for the latest two years. The details of the methods of country allocation are outlined in the trade in services section above. To avoid disclosing data on individual companies the tables have been arranged to remove these disclosive items. This is done wherever possible by suppressing the item so that non-disclosing headings are preserved.

Table 9.12 shows the top 50 trading partners for imports and exports of goods and services for the last two years for which data are available. Again the details of the methods of country allocation are outlined above in the goods and services sections.

Table 9.13 shows estimates of the UK's exports and imports of services with all partner countries for the latest two years. Countries not listed in the tables are assumed to have total transactions in services with the UK of less than $\mathbf{f 0 . 5}$ million. The details of the methods of country allocation are outlined in the section on trade in services above. The data sources which have full country breakdowns of transactions in services are the ITIS survey and the IPS, which between them account for around 70 per cent of the source data for total trade in services. Data from these sources have been used as proxies to estimate the very detailed country breakdowns where these are not available for other data sources.

Table 9.14 shows the UK's data for trade in services compared with world totals and those for G7 countries. The data for these are sourced from the IMF. This data is not available for the latest year as it will not have been published yet. No world balance is included as this should in theory be zero, but in practise because of asymmetries it tends to have either positive or negative values. 